\title{
The impact of coronavirus SARS-CoV-2 (COVID-19) in water: potential risks
}

\author{
Rocío Girón-Navarro ${ }^{1}$ - Ivonne Linares-Hernández ${ }^{1} \cdot$ Luis Antonio Castillo-Suárez $^{1,2}$ (D)
}

Received: 15 May 2021 / Accepted: 14 August 2021 / Published online: 27 August 2021

(C) The Author(s), under exclusive licence to Springer-Verlag GmbH Germany, part of Springer Nature 2021

\begin{abstract}
This review summarizes research data on SARS-CoV-2 in water environments. A literature survey was conducted using the electronic databases Science Direct, Scopus, and Springer. This complete research included and discussed relevant studies that involve the (1) introduction, (2) definition and features of coronavirus, (2.1) structure and classification, (3) effects on public health, (4) transmission, (5) detection methods, (6) impact of COVID-19 on the water sector (drinking water, cycle water, surface water, wastewater), (6.5) wastewater treatment, and (7) future trends. The results show contamination of clean water sources, and community drinking water is vulnerable. Additionally, there is evidence that sputum, feces, and urine contain SARS-CoV-2, which can maintain its viability in sewage and the urban-rural water cycle to move towards seawater or freshwater; thus, the risk associated with contracting COVID-19 from contact with untreated water or inadequately treated wastewater is high. Moreover, viral loads have been detected in surface water, although the risk is lower for countries that efficiently treat their wastewater. Further investigation is immediately required to determine the persistence and mobility of SARS-CoV-2 in polluted water and sewage as well as the possible potential of disease transmission via drinking water. Conventional wastewater treatment systems have been shown to be effective in removing the virus, which plays an important role in pandemic control. Monitoring of this virus in water is extremely important as it can provide information on the prevalence and distribution of the COVID-19 pandemic in different communities as well as possible infection dynamics to prevent future outbreaks.
\end{abstract}

Keywords SARS-CoV-2 $\cdot$ Drinking water $\cdot$ Cycle water $\cdot$ Surface water $\cdot$ Wastewater treatment $\cdot$ COVID-19

\section{Introduction}

The new outbreak of COVID-19 has recently been a serious threat to the health of people around the world. COVID-19 is produced by SARS-CoV-2, which is a single-stranded, positive-sense RNA virus that causes infection and respiratory

Responsible Editor: Lotfi Aleya

Ivonne Linares-Hernández

ilinaresh@uaemex.mx

$\triangle$ Luis Antonio Castillo-Suárez

lacastillosuarez@gmail.com

1 Instituto Interamericano de Tecnología y Ciencias del Agua (IITCA), Universidad Autónoma del Estado de México, Km 14.5 carretera Toluca-Atlacomulco, C.P, 50200 Toluca, Estado de México, Mexico

2 Consejo Mexiquense de Ciencia y Tecnología - COMECYT, Diagonal Alfredo del Mazo 198 y 103, Guadalupe y Club Jardín, C. P. 50010 Toluca de Lerdo, Estado de México, México failure and has led to thousands of deaths (Eslami and Jalili 2020). The current coronavirus pandemic has resulted in huge impacts worldwide. Coronavirus is estimated to infect up to $70 \%$ of the world's population and kill millions of people. The main public health strategy for limiting mortality is to reduce exposure to the virus via physical distancing, which carries tremendous economic costs (Quinete and Hauser-Davis 2021; Stookey et al. 2020).

This abrupt epidemic outbreak of coronavirus disease has currently caused enormous global concerns within the scientific and healthcare community and the general population alike due to the unavailability of human coronavirus vaccines and different virus variants or genetic mutations. Infection with the COVID-19 strain has since spread from Wuhan, China, to approximately 216 countries and territories around the world and has been established as a global pandemic health emergency (Matterne et al. 2020; Kouhsari et al. 2020; Tran et al. 2021). This outbreak is estimated to cause more than 184324 026confirmed cases of COVID-19, 
including 3,992,680 deaths (WHO 2021). As of 7th July 2021 , a total of $3,032,056,355$ vaccine doses were administered.

Faced with this problem, the water is one of the most effective ways to contain the fast-spreading novel coronavirus (COVID-19), however, increased potable water demand and the needs of billions of people living in developing countries that lack access to safe drinking water, facilitate the spread of the virus (Zvobgo and Do 2020). Additionally, the wastewater generated represents a considerable portion of the water consumed, its discharge can contain complex pharmaceuticals, antibiotics, narcotics, radioactive elements, hazardous compounds, and pathogens (Anayah et al. 2021). Wastewater is an ecologically rich environment that contains a plethora of pathogens such as bacteria, fungi, protozoans, toxins, and viruses. Viruses are emerging pathogens and are able to adapt by mutation, recombination, and reassortment and can thus become able to infect new hosts and adjust to new environments. Enteric viruses are among the commonest and most hazardous waterborne pathogens, causing both sporadic and outbreak-related illnesses (Bouseettine et al. 2019). Waterborne enteric viruses, primarily transmitted via fecal-oral route either via person-to-person or interaction or the consumption of contaminated water or food, can pose a serious health hazard to personnel working at wastewater treatment facilities as well as the surrounding community. They find their way into wastewater streams from waste, vomiting, and urine of infected humans as well as animals, hence enter the wastewater stream via infiltration and inflow. Waterborne enteric viruses that are commonly found in wastewater can cause several sporadic cases of diseases and outbreaks because of water or food contamination. Their detection, quantification, and effective removal from wastewater are of great importance because their related diseases result in the death of millions of people across the world, making them a matter of great concern. Adenoviruses (AdVs), coxsackievirus, polioviruses, hepatitis (A and $\mathrm{E}$ ) viruses, rotaviruses, reoviruses, noroviruses (NoVs), and coronaviruses (including SARS-CoV-2) are examples of some viruses that can be detected in wastewater (Ibrahim et al. 2021; Pandey et al. 2021). The ability of some viruses to travel a much greater distance than bacteria in the soil and eventually to groundwater sources due to their sizes and persistence for a considerable period makes their removal difficult and high risk (Adelodun et al. 2021). Waterborne pathogens, including SARS-CoV-2, can be released into the urban-rural water cycle through domestic sewage, urban runoff, agricultural runoff, and wastewater discharges. For this reason, efficient management of the urban-rural water cycle should be considered, as it is essential to understand the transmission of SARS-CoV-2 through different routes before reaching wastewater effluents or surface water such as oceans, rivers, or lakes.

For this reason, a treatments system for drinking water and wastewater consisting of different physical and chemical treatment units can provide multiple barriers to the alleviation of viruses in water (L. Chen et al. 2021). Abatement of waterborne viruses at different treatment processes is reviewed below (coagulation, sedimentation, filtration, and disinfection) for prevention of sewage discharge into freshwater and saltwater are essential to reduce human exposure to the virus (Naddeo and Liu 2020; Sharifi and Khavarian-Garmsir 2020).

The epidemics and pandemics should be included among the natural disasters to which drinking water and wastewater systems are vulnerable. The services provided by drinking water and wastewater utilities are critical to protecting public health, daily life, and economic well-being (Spearing et al. 2020; States 2020; Anayah et al. 2021).

The present review will focus on (a) analyze the characteristics of SARS-CoV-2 and its effects on public health, (b) identify the analytical method for SARS-CoV-2 detection and quantification in water, (c) evaluate the presence of SARS-CoV-2 in drinking water, natural water, and wastewater; (d) compare its environmental impact through the key findings reported by several authors; (e) it will also provide an overview of the potential transmission risks of this novel coronavirus and how COVID-19 could spread in water resources; (f) water and wastewater treatment polluted with SARS-CoV-2. Monitoring effluents from wastewater treatment plants is important to preventing both environmental contamination and the spread of disease and (g) identify the main trends in this field that help future research.

\section{Definition and features of coronavirus}

\section{SARS-CoV-2 structure and classification}

SARS-CoV-2 is a member of an enveloped positive-sense single-stranded ribonucleic acid (RNA) virus family named Coronaviridae belonging to the Nidovirales order. It is spherical, has a diameter of approximately $65-125 \mathrm{~nm}$, and has crown-like spikes on the outer surface (Astuti and Ysrafil 2020). Enveloped proteins are involved in several aspects of the virus life cycle, such as assembly, envelope formation, and pathogenesis. Inside the envelope is the helical capsid containing nucleoprotein and the RNA genome (up to 33.5 kilobases (kb) genomes) (La Rosa et al., 2020c; Fehr and Perlman 2015). Coronaviridae is divided into two subfamilies: Coronavirinae and Torovirinae. Coronavirinae is then further classified into alpha, beta, gamma, and delta coronavirus (Ullah et al. 2020). Respiratory infection in humans is usually caused by alpha and beta coronaviruses, which cause mild to severe lower respiratory tract disease. Several human coronaviruses. Middle East respiratory syndrome coronavirus (MERS-CoV), severe acute respiratory syndrome coronavirus (SARS-CoV), and acute respiratory distress syndrome (ARDS)) have been identified, and they can be transmitted 
by humans via droplets and contact (Chen et al. 2020; Li et al. 2020). Occasionally, new variants of coronaviruses emerge due to their genetic diversity, rapid mutation, high prevalence, and wide distribution (Ullah et al. 2020; Mandal et al. 2020).

\section{Infectious structures of SARS-CoV-2}

Coronaviruses usually have a spike (S), envelope (E), membrane $(\mathrm{M})$, and nucleocapsid $(\mathrm{N})$ as structural proteins. Through the $\mathrm{S}$ protein, this virus enters the host cell, and it is cut up by the host protease into two functional subunits, $\mathrm{S} 1$ and S2, which oversee host cell binding and viral-cellular membrane fusion, respectively. Several CoVs recognize different proteases and entry receptors, where SARS-CoV and SARS-CoV-2 process their S protein by employing the cellular serine called protease TMPRSS2 and subsequent interaction with angiotensin-converting enzyme two (ACE2) cellular receptors (Zhou et al. 2021; Scagnolari et al. 2021). These viral components can be used for drug therapy against COVID-19. The pathophysiology of SARS-CoV-2 is not well understood, but similar to SARS-CoV, viral replication leads to aggressive inflammation and causes acute lung injury (Scagnolari et al. 2021).

This virus infects humans and animals, causing hepatic, gastrointestinal, neurologic, and respiratory illnesses (Ullah et al. 2020).

\section{The effects of SARS-CoV-2 on public health}

Global coronavirus disease 2019 (COVID-19) affects the economy, environment, people's livelihoods, and mainly their health (Rume and Islam 2020). For this reason, several studies have reported its effects on the physical and mental health of children, teenagers, young adults, and elderly adults (Di Santo et al. 2020).

Regarding physical health, COVID-19 is a viral respiratory infection that is easy to spread due to the rapid transmission via the respiratory tract from person to person (Naser et al. 2020). Concerning mental health, people with pre-existing mental illness and substance use disorders will be at increased risk of infection with COVID-19 (Cullen et al. 2020). From 2020 to 2021 , the percentage of total studies on the effects of COVID-19 was $44 \%$ for mental health and $34 \%$ for physical health, while $22 \%$ of publications covered both $(n=32$ (Banerjee et al. 2020). Table 1 summarizes the effects of COVID-19 on public health linked to age group for comparison.

\section{SARS-CoV-2 transmission}

The main route of transmission of SARS-CoV-2 is either by direct contact with an infected subject or indirect contact through a hand-mediated transfer of the virus from contaminated fomites to the mouth, nose, or eyes or via respiratory droplets generated by breathing, sneezing, coughing, etc., (La Rosa et al., 2020a), but knowledge about other potential modes of transmission, e.g., fomite-based, vertical, and fecal-oral transmission, remains sparse (Amirian 2020). The wastewater plumbing system is believed to have acted as a potential route of transmission and caused the superspreading occurrence in Hong Kong due to the transportation of "virus-laden droplets." The presence of SARS-CoV-2 nucleic acids has been reported in raw wastewater, sewage samples collected from hospitals, and wastewater samples after secondary treatment (Mandal et al. 2020; Sepúlveda-Loyola et al. 2020; Amirian 2020; Lapolla et al. 2020; Ahmed et al. 2020a; Cuevas-Ferrando et al. 2021).

\section{Initial transmission}

The bat is the largest natural host of the $\alpha$ - and $\beta$ coronaviruses due to its adapted immune system (Kitajima et al. 2020; Street et al. 2020). COVID-19 clinical case-isolated coronavirus has a taxonomic homology $>95 \%$ to bat coronavirus (Parthasarathy and Vivekanandan 2021). There is evidence that human coronaviruses have a zoonotic origin (Drexler et al. 2014) and that at some point in their evolution, these viruses became able to infect people. Figure 1 shows the likely mechanism for starting virus transmission.

It was thought that the transmission of SARS-CoV-2 was made possible by the consumption of bats in the food market of the city of Wuhan, and thus transmission to humans was possible (Shereen et al. 2020; Adelodun et al. 2020). Some viruses are easily denatured by the increase in temperature during the food cooking process between 56 and $60{ }^{\circ} \mathrm{C}$ (Chida et al. 2021), and SARS-CoV-2 has shown a low affinity for the $\mathrm{ACE} 2$ receptor, a protein responsible for initiating the infectious process in human cells, above $40{ }^{\circ} \mathrm{C}$ (Shereen et al. 2020; Chida et al. 2021). Thus, consuming this processed food could not be the cause of the initial transmission.

The virus developed the ability to use ACE2 as a receptor in host cells (Street et al. 2020; Wan et al. 2020). This capability may have been the result of the natural evolution of the virus or a modification acquired in another intermediate zoonotic host (Wan et al. 2020). The chances of coming into contact with humans are higher and transmission is more probable (Platto et al. 2020) when you have daily human contact with the animal host for a long time.

\section{Primary transmission mechanism}

Primary transmission occurs from contact with droplets that are dispersed by the coughing or sneezing of an infected or asymptomatic individual (Rothan and Byrareddy 2020), and transmission of the virus occurs by person-person contact, 
Table 1 Effect of COVID-19 on mental and physical health

\begin{tabular}{|c|c|c|c|}
\hline Age group & Mental health & Physical health & Author, year \\
\hline Children ( $0-12$ years) & $\begin{array}{l}\text { Acute stress disorder, adjustment disorder, } \\
\text { post-traumatic stress disorder, worry, anxiety, } \\
\text { and fear. }\end{array}$ & $\begin{array}{l}\text { - The economic crisis increases stress, violence, } \\
\text { and parental abuse against children. }\end{array}$ & (Kontoangelos et al. 2020) \\
\hline $\begin{array}{l}\text { Adolescents }(13-17 \\
\text { years) }\end{array}$ & $\begin{array}{l}\text { Post-traumatic stress symptoms, depression, low } \\
\text { mood, irritability, insomnia, and anger. } \\
\text { Emotional exhaustion due to reorganization of } \\
\text { family life, fear of death of relatives, massive } \\
\text { stress, and anxiety for the economic crisis. }\end{array}$ & $\begin{array}{l}\text { - Increase in physical and sexualized violence } \\
\text { against adolescents, as well as multiple cases } \\
\text { of self-injurious and suicidal behavior. } \\
\text { - Drug and alcohol abuse has increased during } \\
\text { this pandemic. }\end{array}$ & $\begin{array}{l}\text { (Banerjee et al. 2020; } \\
\quad \text { Kontoangelos et al. 2020) }\end{array}$ \\
\hline $\begin{array}{l}\text { Young adults }(18-35 \\
\text { years) }\end{array}$ & $\begin{array}{l}\text { Depression, stress, and reduced sleep quality. } \\
\text { Indeed, delays in university activities due to } \\
\text { COVID-19 have been correlated with anxiety. } \\
\text { Also, higher panic and fear levels because of } \\
\text { information through social media. }\end{array}$ & $\begin{array}{l}\text { - Symptoms are fever, cough, shortness of breath } \\
\text { or difficulty breathing, chills, fatigue, muscle } \\
\text { pain, headache sore throat, loss of smell or } \\
\text { taste, runny nose, nausea, or diarrhea. } \\
\text { - Most infections are asymptomatic or do not } \\
\text { require hospitalization/treatment. However, a } \\
\text { study shows that young people who } \\
\text { contracted COVID-19 and require hospitali- } \\
\text { zation ended up in intensive care/were placed } \\
\text { on a breathing machine/died. Patients with } \\
\text { multiple risk factors (morbid obesity, } \\
\text { hypertension, and diabetes) faced severe } \\
\text { cases. }\end{array}$ & $\begin{array}{l}\text { (WHO 2020; Fegert et al. 2020; } \\
\text { Clay and Parker 2020) }\end{array}$ \\
\hline $\begin{array}{l}\text { Middle-aged adults } \\
\quad(36-55 \text { years })\end{array}$ & $\begin{array}{l}\text { Negative changes in physical activity, sleep, } \\
\text { smoking, and alcohol consumption. Increased } \\
\text { depression, anxiety, distress, irritability, } \\
\text { fearfulness, insomnia, oppositional behaviors, } \\
\text { and somatic complaints. Some levels of panic, } \\
\text { mental health issues, psychotic symptoms, } \\
\text { and even suicide, were reported during the } \\
\text { early severe acute respiratory syndrome } \\
\text { outbreak. }\end{array}$ & $\begin{array}{l}\text { - COVID-19 symptoms include fever, dry cough, } \\
\text { nasal congestion, shortness of breath, fatigue, } \\
\text { diarrhea, and vomiting. } \\
\text { - Some patients, gradually deteriorate, with the } \\
\text { involvement of internal organs such as the } \\
\text { lungs, kidneys, and heart. } \\
\text { - Complications after admission include } \\
\text { secondary infection, acute heart injury, and } \\
\text { acute liver and kidney injury. }\end{array}$ & $\begin{array}{l}\text { (Lekamwasam and } \\
\text { Lekamwasam 2020; Clay and } \\
\text { Parker 2020; Cunningham } \\
\text { et al. 2020; Tarighi et al. } \\
\text { 2021; }\end{array}$ \\
\hline $\begin{array}{l}\text { Older adults }(>55 \\
\text { years) }\end{array}$ & $\begin{array}{l}\text { Anxiety, depression, sleep disturbances, high } \\
\text { levels of psychological stress, and loneliness } \\
\text { were observed during the lockdown by a } \\
\text { coronavirus. }\end{array}$ & $\begin{array}{l}\text { - Clinical symptoms include cough, sputum, } \\
\text { chest tightness, difficulty breathing, fever, } \\
\text { fatigue, nasal congestion, runny nose sick, } \\
\text { vomit, and pneumonia severity index. } \\
\text { Complication after hospitalization: acute } \\
\text { respiratory distress syndrome, acute heart } \\
\text { injury, secondary infections, shock, and death. } \\
\text { - Elderly patients are prone to multi-system organ } \\
\text { dysfunction and even failure, including gas- } \\
\text { trointestinal bleeding, renal failure, DIC, or } \\
\text { deep vein thrombosis. }\end{array}$ & $\begin{array}{l}\text { (Lekamwasam and } \\
\text { Lekamwasam 2020; Feroz } \\
\text { et al. 2020) }\end{array}$ \\
\hline
\end{tabular}

which is favored at a distance $<1.5 \mathrm{~m}$ (Fig. 1) (Drexler et al. 2014; Manigandan et al. 2020b). Human and social proximity increases the transmission of the virus (Manigandan et al. 2020b).

Primary transmission epithelial cells of the host lung are infected by the virus through recognition of the membrane protein ACE2 by the glycoprotein S of SARS-CoV-2 (Rothan and Byrareddy 2020). The ACE2 protein is expressed primarily in type II alveolar cells, airway epithelial cells, fibroblasts, endothelial cells, and various immune cells (Belete 2020).

\section{Secondary transmission mechanisms}

Surfaces contaminated with drops of body fluids from symptomatic or asymptomatic patients, such as door handles, elevator buttons, tables, and glasses, become secondary mechanisms of transmission (Fig. 1) (Shang et al. 2021). Touching surfaces and tools contaminated with the virus increase the risk of contagion (Manigandan et al. 2020b). Transmission is possible through the ocular surface, nose, and mouth ( $\mathrm{Lu}$ et al. 2020).
Medical procedures such as endoscopies or dental treatments can also be a transmission mechanism (Manigandan et al. 2020b). In these transmission mechanisms, there is no direct contact with an infected person; therefore, all different means can be considered secondary mechanisms.

Airborne transmission of SARS-CoV-2 is critical, and this mechanism has been confirmed. hospital room has been isolated (Fig. 1) (Noorimotlagh et al. 2021).

The SARS-CoV-2 virus has been isolated and identified in hospital wastewater (Fig. 1) (Gonçalves et al. 2021). The virus has been identified in fecal excretions, and wastewater from hospitals and households has a high viral concentration of $10^{4}$ genomic copies/L (GC/L) (Gholipour et al. 2021).

Contact with SARS-CoV-2 wastewater aerosols may be a secondary mechanism of transmission (Fig. 1), and these wastewater aerosols can come into contact with workers in wastewater treatment plants (Gholipour et al. 2021). Hospitalized patients or those isolated at home can spread the virus through wastewater. In countries where wastewater is not treated, the risk of transmission is greater (Adelodun et al. 2020). 


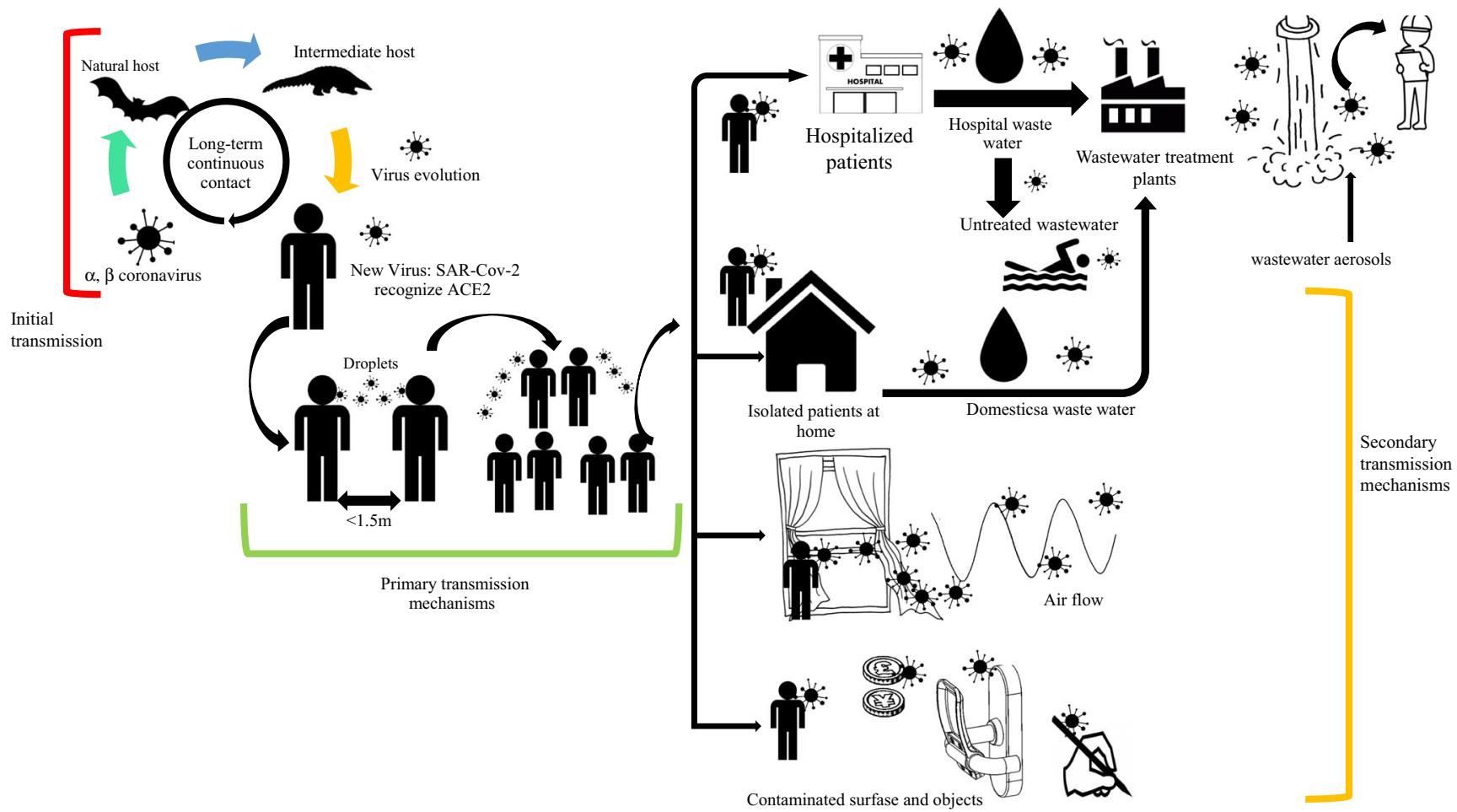

Fig. 1 Transmission mechanisms virus SARS-CoV-2

Secondary transmission mechanisms represent an important means of contagion, and prevention measures should consider containment strategies to combat SARS-CoV-2 disease by controlling these mechanisms.

\section{Analytical methods for SARS-CoV-2 detection}

The recent spread of SARS-CoV-2, exemplifies the critical need for accurate and rapid diagnostic assays. Since the WHO provided the diagnostic protocol on January 13, 2020, clinical and research health laboratories have quickly developed a series of diagnostic kits for COVID-19 (Vogels et al. 2020; Corman et al. 2020).

The most widely used assay is real-time PCR (RT-PCR) (Celis et al. 2021). Which is used for the molecular diagnosis of SARS-CoV-2. Several protocols in laboratories include the RNA extraction and purification process before RT-PCR as a necessary step for the measurement of viral RNA loads, as it isolates genomic RNA from the viral capsid and removes PCR inhibitors from the original material (Deiana et al. 2020).

RT-PCR proceeds with laboratory conversion of viral genomic RNA into DNA by RNA-dependent DNA polymerase (reverse transcriptase), as shown in Fig. 2. This reaction hangs on small DNA sequence primers designed to recognize complementary sequences on the RNA viral genome and the reverse transcriptase to generate a short complementary DNA copy (cDNA) of the viral RNA.
SARS-CoV-2 detection and COVID-19 diagnosis depend on RT-qPCR tests, and results are usually reported as positive or negative. However, the test can also provide a measure of the viral load in the sample, called a cycle threshold value ( $\mathrm{Tu}$ and O'Leary 2020).

The RT-PCR test provides real-time quantification by reverse transcription of SARS-CoV-2 RNA into DNA, and after performing PCR, the fluorescence signal increases proportionally to the amount of nucleic acid amplified, which allows accurate quantification of RNA in the sample. If the fluorescence reaches a specified threshold within a certain number of PCR cycles (Ct value), the sample is considered positive (Manigandan et al. 2020a). $\mathrm{Ct}<40$ is considered positive, allowing the detection of very few starting RNA molecules. The cycle threshold $(\mathrm{Ct})$ value from the RT-PCR is inversely proportional (on a logarithmic scale) to viral load; hence, lower $\mathrm{Ct}$ values correspond to higher viral loads (Trang et al. 2015).

\section{SARS-CoV-2 detection in environmental water samples}

One common method is to quantify the amount of viral RNA in an environmental water sample via RT-qPCR. This method can measure the number of viral RNA copies or genomic copies in water samples such as surface water or wastewater (Rodríguez et al. 2009; Bar-On et al. 2020). However, virus concentration steps will likely be necessary 


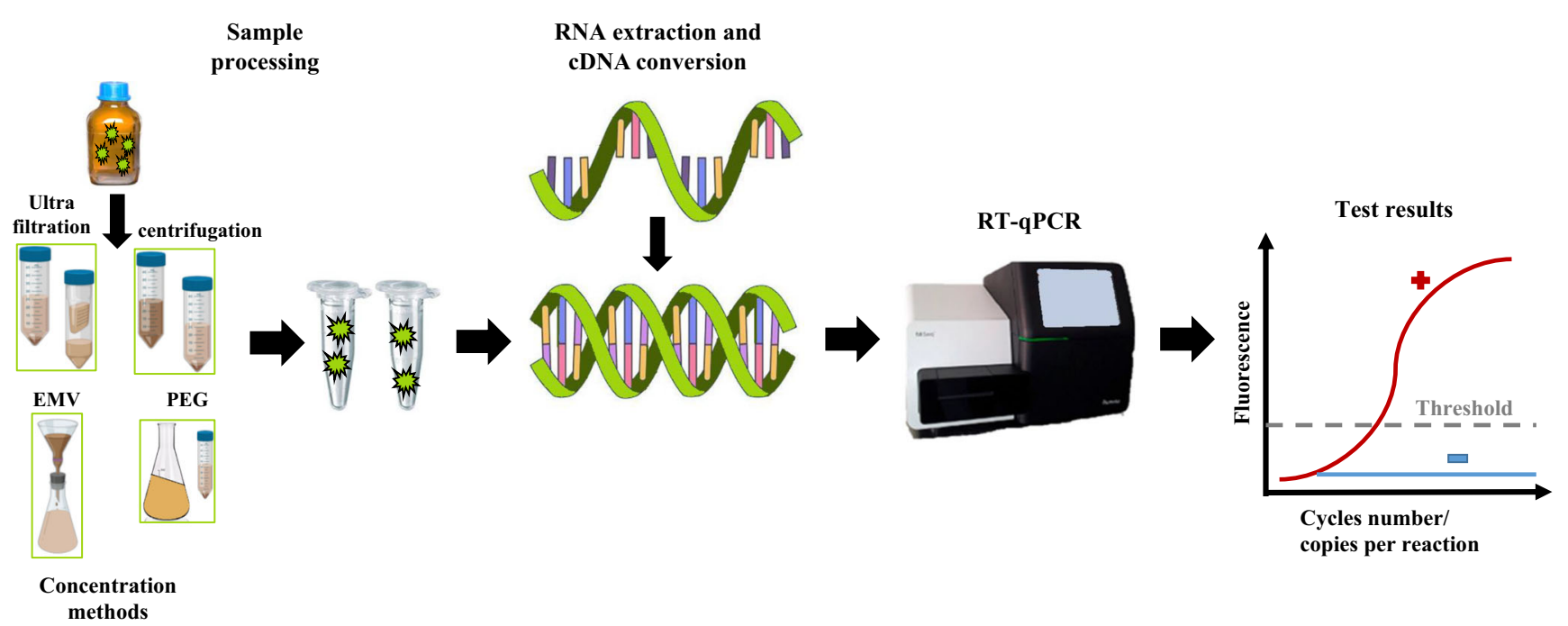

Fig. 2 Real-time RT-PCR analysis of samples to detect SARS-CoV-2 in water

before subsequent detection of SARS-CoV-2 in samples, as shown in Fig. 2 (Nemudryi et al. 2020; Wurtzer et al. 2020a; Medema et al. 2020).

Several methods have been developed for concentrating viruses in water samples, such as electropositive or electronegative membranes. Another membrane-based method used for concentrating viruses in environmental water samples is ultrafiltration, which is based on size exclusion. Other methods, including polyethylene glycol (PEG), ultracentrifugation, and skimmed milk flocculation, have also been used for concentrating viruses from water samples (Lapolla et al. 2020; Haramoto et al. 2020; Sherchan et al. 2020).

Concentration volumes of water are important factors that should be considered in the results of detection of viruses; usually, concentrating $<100 \mathrm{~mL}$ of untreated water samples is sufficient to detect enteric viruses (Haramoto et al. 2018; Medema et al. 2020). Detection of SARS-CoV-2 is principally based on RT-qPCR, and their results are usually reported in RNA copies per reaction or genomic copies within a concentration volume, such as liters, milliliters, or cubic meters (Corman et al. 2020; Shirato et al. 2020).

Absolute or relative quantification can be used when calculating the results of the RT-qPCR assay: the first is used to quantify unknown samples by interpolating their quantity from a standard curve, and the second is used to analyze changes in gene expression in a given sample relative to another aqueous reference sample. The calculation methods usually used for relative quantitation are the standard curve method and comparative cycle threshold method, as shown in Fig. 2 (Boulter et al. 2016; Vogels et al. 2020; Arnaout et al. 2020).

\section{Environmental impact associated with SARS-CoV-2 in water}

\section{Drinking water}

Drinking water is derived from either surface waters, comprising rivers, streams, wetlands, and lakes, or groundwater. However, several contaminants of public health importance naturally occur in these water bodies. For example, metals may originate from natural geochemical lithosphere conditions, and geological processes, in addition to anthropogenic activities, have led to extensive contamination by thousands of chemicals. In general, urbanization and industrialization processes and agriculture and forestry activities are considered the two major contaminant inputs for these freshwater water bodies (Quinete and Hauser-Davis 2021). Currently, clean water sources and community drinking water are vulnerable to stool contamination, and there is evidence that sputum, feces, and urine contain SARS-CoV-2 (Purnama and Susanna 2020; Bilal et al. 2020).

SARS-CoV-2 virus has recently been reported in wastewater. It is possible that patients diagnosed with coronavirus disease are the main route of coronavirus transmission to water and sewage (Tran et al. 2021). Detection of SARS-CoV-2 RNA in wastewater is of interest as it can be used as an early warning method to detect the contact risk associated with untreated water or inadequately treated wastewater (García-Ávila et al. 2020).

Waterborne viruses are different regarding their genome contents and capsid proteins, but such viruses have some common attributes, making them of specific interest concerning the risk of disease endemics related to drinking water infections. According to Hoseinzadeh et al. 2020, water-spread 
viral pathogens, categorized in terms of moderate to high health importance, consist of adenovirus, astrovirus, hepatitis $A$ and $E$ viruses, rotavirus, norovirus, and other caliciviruses, as well as enteroviruses, including coxsackieviruses and polioviruses. Additionally, urine urinary excretion viruses (e.g., polyomaviruses and cytomegalovirus) have the potential to be disseminated via water. Other viruses (e.g., influenza and coronaviruses) have been considered organisms that are transmittable by drinking water, but the evidence is indecisive. Table 2 shows examples of viruses found in samples of drinking water, and some treatments are reported to remove or reduce these pathogens. SARS-CoV-2 has not yet been found in any drinking water facilities, and per current evidence, it is safe to comment that the risk to drinking water supplies is low if proper precautions are being taken (Bhowmick et al. 2020).

The SARS-CoV-2 virus has been detected in fecal samples and consequently in untreated wastewater. The fecal-oral route of transmission has possible subpathways: contaminated drinking water, contaminated raw and undercooked aquatic, marine, aquacultural, and sewage-irrigated food, and vector-mediated transmission. Contamination of drinking water sources can occur through seepage from sanitation systems (pit latrines and septic tanks), landfills leachates without geomembrane protection towards the shallow groundwater systems. One study reported $99.9 \%$ mortality after 10 days in tap water at $23{ }^{\circ} \mathrm{C}$ and over 100 days at 4 ${ }^{\circ} \mathrm{C}$ in other types of coronaviruses. This finding also suggests a longer survival time of coronaviruses in tap water than in wastewater (Gwenzi 2021).

Water for human consumption is treated by conventional methods with correct chlorine-based disinfection and ensuring a residual chlorine level of $0.5 \mathrm{mg} / \mathrm{L}$. Chlorine has also been shown to be more effective in inactivating SARS-CoV-2 than chlorine dioxide and other chemical products (García-Ávila et al. 2020). SARS-CoV-2, an enveloped virus, does not survive easily in water and is able to eliminate and inactivate itself efficiently. International and local regulations have launched treatment requirements so that waterborne pathogens, such as viruses, do not attain drinking water systems. The survival of SARS-CoV-2 in wastewater treatment and drinking water supplies is a global concern (García-Ávila et al. 2020).

The World Health Organization (WHO) noted that the accessibility of drinking water is a fundamental condition for the safety of people. It is widely documented how unsafe water has been suspected to be the cause of epidemics since ancient times(Balacco et al. 2020). The absence of evidence on the survival of COVID-19 in drinking water is valuable because it could improve the hygienic conditions of people and prevent the spread of the virus (Balacco et al. 2020; WHO 2021).

Further investigation is urgently required to determine the persistence and infectivity of SARS-CoV-2 in polluted water and sewage as well as the potential of disease transmission via exposure to contaminated water matrices. This might be of critical importance in controlling COVID-19 in vulnerable communities and crisis zones with poor access to water, sanitation, and hygiene (Carraturo et al. 2020; Kassem and Jaafar 2020).

\section{The urban and rural water cycle}

Waterborne pathogens, which are divided into three main categories, i.e., viruses, bacteria, and parasites (Bridle 2014), can be released into the urban water cycle through domestic sewage, urban runoff, agricultural runoff, and wastewater discharges (Bar-Or et al. 2020).

Appropriate management of the urban and rural water cycle is essential to contain the spread of SARS-CoV-2 since the disease it causes can spread through fecal-oral routes. Correct disinfection of drinking water and wastewater treatment plants and measures such as prevention of sewage leakage into freshwater resources are essential to reduce human exposure to the virus (Naddeo and Liu 2020; Sharifi and Khavarian-Garmsir 2020).

SARS-CoV-2 can maintain its viability in sewage and the urban-rural water cycle, originating from the fecal discharge of infected patients and moving to different bodies of water through the pathways shown in Fig. 3 (Bhowmick et al. 2020).

Several studies have reported the presence of SARS-CoV-2 in urban and rural sewerage systems. This sewage has the possibility to contaminate freshwater; it can cross untreated effluent discharges to surface water or leaks, as well as affect the supply of traditionally treated graywater, and thus these recycled urban waters also represent possible transmission methods (Mukherjee et al. 2020). Table 3 shows these studies in urban and rural sewage.

According to the table above, multiple authors have detected SARS-CoV-2 in the sewage from urban and rural areas, which confirms its mobility and presence in the water cycle, represented in Fig. 3.

The quantification method used in all studies was real-time polymerase chain reaction (RT-PCR), and virus concentrations were reported as cycle thresholds $(\mathrm{Ct})$ and copy numbers per liter. $\mathrm{Ct}<29$ values corresponded to raw sewage in India, while countries such as Israel, the USA, and Spain presented $\mathrm{Ct}>30$ but below cycle 40 . It is important to note that a sample is considered positive when the cycle threshold $(\mathrm{Ct})$ took place below cycle 40. In the Northeastern U.S. metropolitan area, a primary sewage sludge exhibited the highest virus RNA copies per liter, and the sewage in Quito contained the lowest copies per liter.

The detected concentrations of SARS-CoV-2 in different countries indicate its high persistence in sewage, and thus the monitoring of the virus in these effluents is extremely important because it can provide information on the prevalence, 


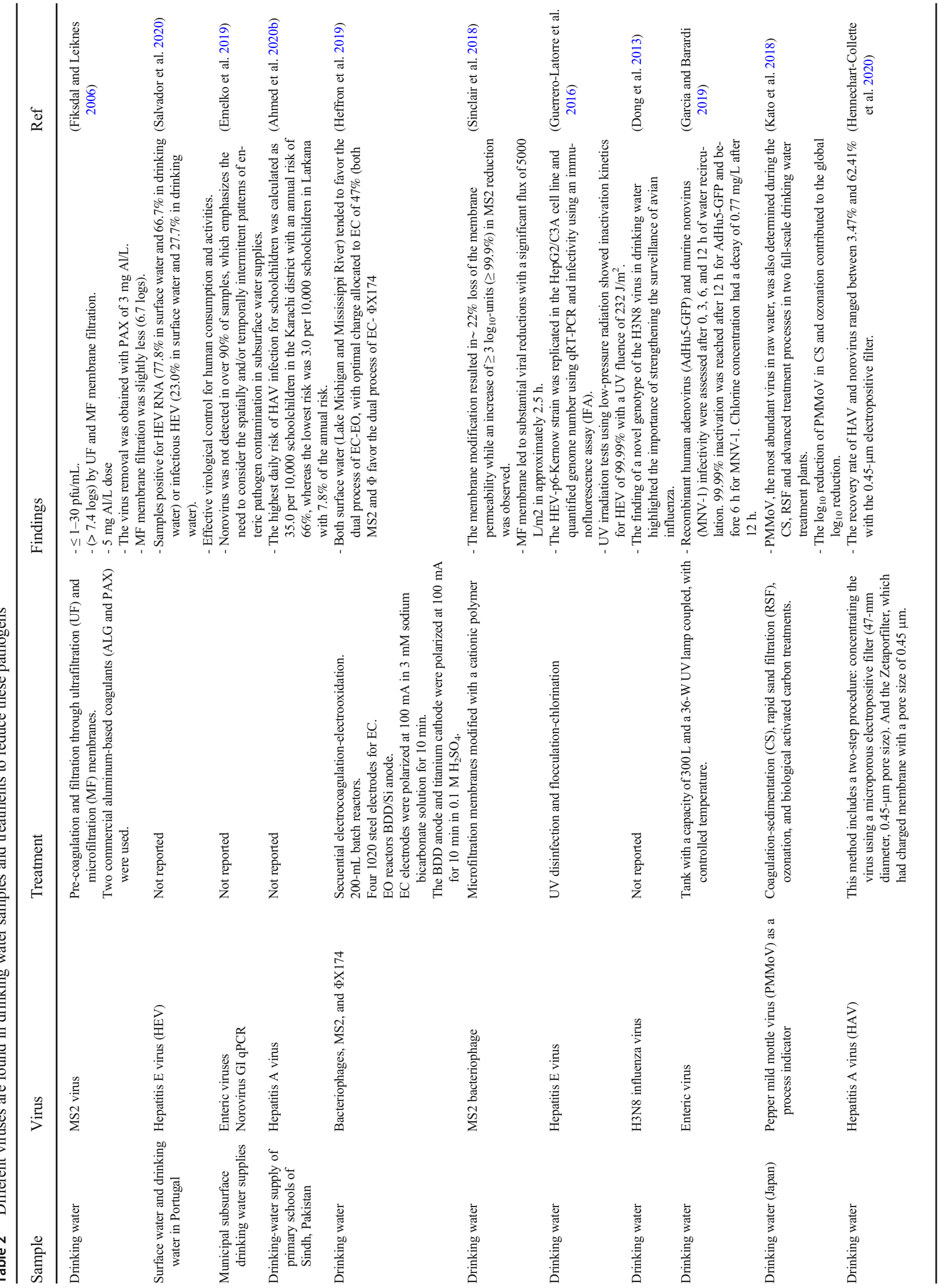



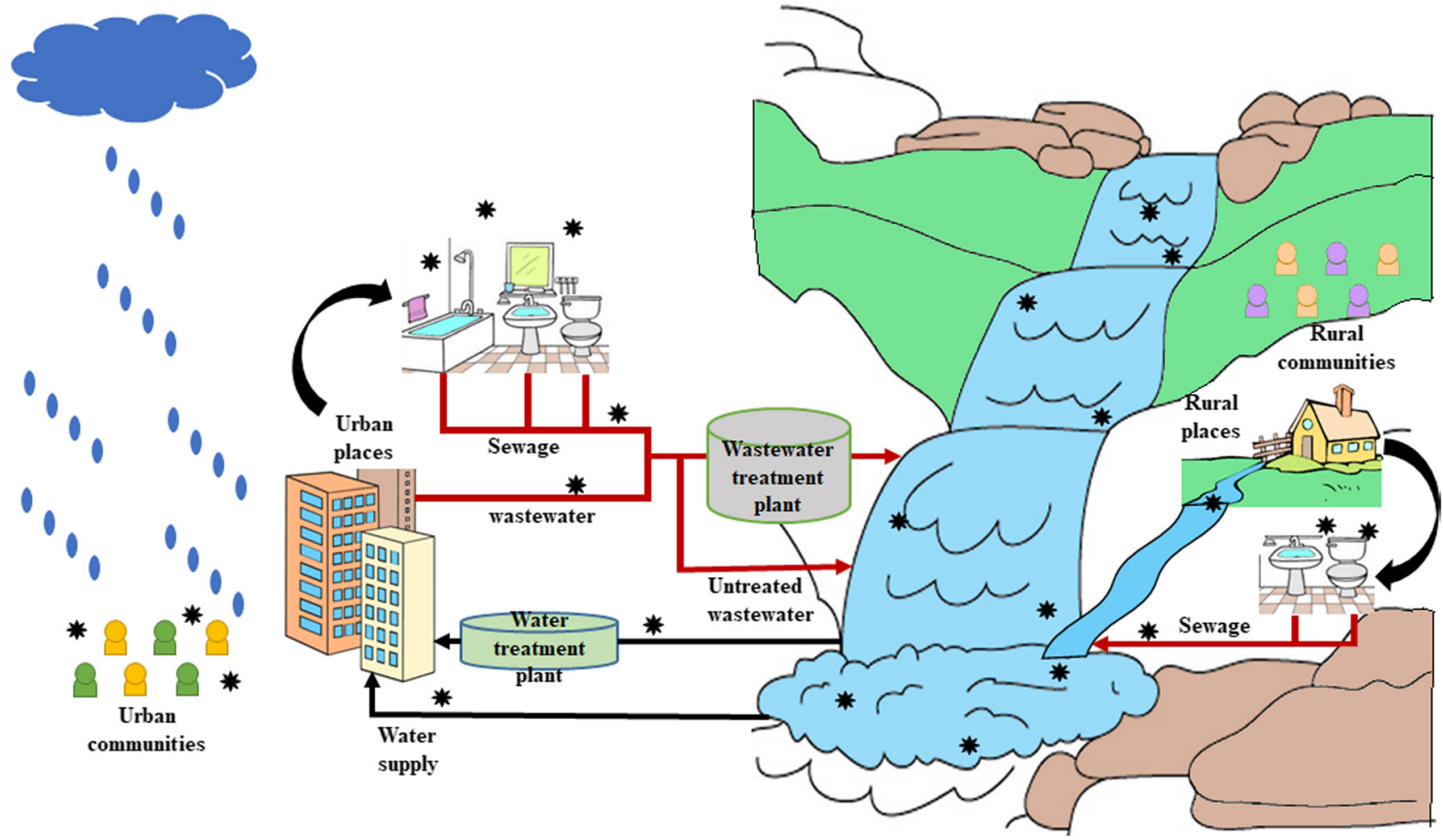

Fig. 3 Contamination system of SARS-CoV-2 in the rural and urban water cycle with human exposure

distribution in communities, and possible infection dynamics to prevent future outbreaks and evaluate virus elimination.

Urban sewer systems are usually more representative samples of communities than wastewater because wastewater is collected from the population through interceptors that are used to divide the study people. If higher viral loads are observed in one interceptor than in the rest, the corresponding service area will be of greater concern for a possible viral outbreak (O'Brien and Xagoraraki 2019). Taking samples in rural areas is more complex than in urban areas due to the nonexistence of wastewater collection systems and the proximity of discharges to surface waters (Polo et al. 2020).

The COVID-19 pandemic influences multiple aspects of urban and rural water areas, such as engineering, sanitary, economic, and social aspects, which will have important effects in the future (Poch et al. 2020). Table 4 summarizes the publications that report the impacts of COVID-19 on the management of the water cycle in urban and rural areas.

As seen in Table 4, there are several impacts of the COVID-19 pandemic on the management of the urban and rural water cycles. In rural communities, impacts such as water supply programs, water scarcity and quality, disruption of activities in agriculture and supply chains, and ensuring water resources to basic needs are mentioned.

On the other hand, urban areas have shown these impacts: the COVID-19 pandemic affects economic-social water aspects, water policies must be improved for equitable distribution and sewage is a critical tool for monitoring the COVID-19 pandemic because SARS-CoV-2 can maintain its viability in sewage. However, a positive effect that some studies report is that the COVID-19 lockdown has reduced water contamination in multiple urban cities.

\section{Surface water}

SARS-CoV-2 presence in surface water, including both saltwater and freshwater, was confirmed in some regions with a high prevalence of COVID-19 disease. Moreover, the presence of coronaviruses from anthropogenic activities was confirmed in different water bodies (La Rosa et al. 2020a; Sivakumar 2020).

It is important to understand the mobility of SARS-CoV-2 in the water environment to ensure that public health protection measures are properly established (Naddeo and Liu 2020). However, there are limited data on the presence of viral loads in water bodies due to sewage discharged (Cahill and Morris 2020). It is important to conduct studies that address these issues to develop solutions that help developing countries with poor water and sewage infrastructure (Al Huraimel et al. 2020).

SARS-CoV-2 can be spread to water ecosystems due to leaking sewers or deficient removal after sewage treatment (Wurtzer et al. 2020a). Moreover, rainfall events can increase virus concentrations in natural water systems through 
Table 3 Detection of SARS-CoV-2 in urban-rural sewage by several authors

\begin{tabular}{|c|c|c|c|c|c|}
\hline $\begin{array}{l}\text { Sample } \\
\text { type/country }\end{array}$ & Quantification method & $\begin{array}{l}\text { Concentration } \\
\text { methods }\end{array}$ & Virus concentration & Key findings & Reference \\
\hline Raw sewage/Israel & PCR system & $\begin{array}{l}\text { Polyethylene glycol } \\
\text { (PEG) or alum } \\
\text { precipitation }\end{array}$ & $\begin{array}{l}\text { Tel Aviv: } \\
\text { qPCR Ct of } 33 \text { and } 33.6 \\
\text { Bnei Brak city: } \\
\text { qPCR Ct of } 33-37 \text {. } \\
\text { Beer Sheva and Haifa: } \\
\text { negative }(\mathrm{Ct}>40) \text {. }\end{array}$ & $\begin{array}{l}\text { - This study shows a } \\
\text { proof-of-concept for the } \\
\text { detection of SARS-CoV-2 } \\
\text { RNA in sewage. } \\
\text { - Results will enable early } \\
\text { identification and } \\
\text { spatial-based monitoring of } \\
\text { future outbreaks and be used } \\
\text { to confirm virus elimination. }\end{array}$ & $\begin{array}{l}\text { (Bar-Or et al. } \\
\text { 2020) }\end{array}$ \\
\hline $\begin{array}{l}\text { Primary sewage } \\
\text { sludge/Northeast- } \\
\text { ern U.S. } \\
\text { metropolitan area }\end{array}$ & $\begin{array}{l}\text { Quantitative reverse } \\
\text { transcriptase-- } \\
\text { polymerase chain } \\
\text { reaction (qRT-PCR) }\end{array}$ & Not reported & $\begin{array}{l}\text { Samples ranged from } 1.7 \times 10^{3} \\
\text { to } 4.6 \times 10^{5} \text { virus RNA } \\
\text { copies } \mathrm{mL}^{-1} \text {. } \\
\text { The lower concentration in this } \\
\text { range corresponds to a } \\
\text { qRT-PCR cycle threshold } \\
(\mathrm{Ct}) \text { value of } 38.75 .96 .5 \% \text { of } \\
\text { all CT values were less than } \\
38 \text {. }\end{array}$ & $\begin{array}{l}\text { - SARS-CoV-2 RNA is present } \\
\text { in the stool of COVID-19 } \\
\text { patients and thus in raw } \\
\text { sewage. } \\
\text { - Monitoring it in a } \\
\text { community's collection } \\
\text { system can provide } \\
\text { information on the } \\
\text { prevalence and dynamics of } \\
\text { infection for the population. }\end{array}$ & $\begin{array}{l}\text { (Peccia et al. } \\
\text { 2020) }\end{array}$ \\
\hline Raw sewage/Turkey & $\begin{array}{l}\text { Quantitative reverse } \\
\text { transcription PCR } \\
\text { (RT-qPCR) }\end{array}$ & $\begin{array}{l}\text { Ultracentrifugation, } \\
\text { polyethylene glycol } \\
\text { adsorption, } \\
\text { electronegative } \\
\text { membrane, and } \\
\text { ultrafiltration } \\
\text { methods }\end{array}$ & $\begin{array}{l}\text { Ambarli, Pasakoy, Kadikoy, } \\
\text { Terkos, Buyukcekmece, } \\
\text { Baltalimani and Tuzla points: } \\
8.26 \times 10^{3}, 1.80 \times 10^{4}, \mathrm{ND}, \\
\mathrm{ND}, 3.73 \times 10^{3}, 4.95 \times 10^{3}, \\
2.89 \times 10^{3} \mathrm{SARS}-\mathrm{CoV}-2 \\
\text { copy numbers per liter, } \\
\text { respectively. }\end{array}$ & $\begin{array}{l}\text { - SARS-CoV-2 in raw sewage } \\
\text { can be used as a tool in } \\
\text { wastewater-based } \\
\text { epidemiology and it can } \\
\text { provide information about } \\
\text { SARS-CoV-2 distribution in } \\
\text { the wastewater of various } \\
\text { districts of Istanbul. }\end{array}$ & $\begin{array}{l}\text { (Kocamemi et al. } \\
\text { 2020a) }\end{array}$ \\
\hline Raw sewage/India & RT-PCR analysis & $\begin{array}{l}\text { Filtration and } \\
\mathrm{PEG} / \mathrm{NaCl} \\
\text { adsorption method }\end{array}$ & $\begin{array}{l}\text { Four samples with } \mathrm{Ct} \text { of } 25.5 \text {, } \\
34.1,23.7 \text {, and } 25.9\end{array}$ & $\begin{array}{l}\text { - SARS-CoV-2 RNA is present } \\
\text { in hospital sewage samples } \\
\text { of India. } \\
\text { - These findings demonstrate } \\
\text { the applicability of WBE or } \\
\text { sewage surveillance as an } \\
\text { early indicator of the } \\
\text { persistence of the virus in the } \\
\text { community and the risk } \\
\text { associated with wastewater } \\
\text { handling. }\end{array}$ & (Arora et al. 2020) \\
\hline $\begin{array}{c}\text { Primary sewage } \\
\text { sludge/Spain }\end{array}$ & RT-PCR detection & $\begin{array}{l}\text { Ultrafiltration and } \\
\mathrm{PEG} / \mathrm{NaCl} \\
\text { precipitation }\end{array}$ & $\begin{array}{l}\text { April 7: Ct of } 34.3,36.0 \text { and } \\
\quad 39.8 \\
\text { April 16: Ct of } 33.4,35.9 \text {, and } \\
\quad 36.6\end{array}$ & $\begin{array}{l}\text { - Based on the destination of } \\
\text { the viral particles, ideal } \\
\text { places must be identified to } \\
\text { detect COVID-19 incidence } \\
\text { and monitor its evolution. } \\
\text { - The primary and thickened } \\
\text { sludge showed higher } \\
\text { concentrations, suggesting } \\
\text { that COVID-19 incidence } \\
\text { could be monitored in the } \\
\text { sludge line. }\end{array}$ & $\begin{array}{l}\text { (Balboa et al. } \\
\text { 2021) }\end{array}$ \\
\hline $\begin{array}{l}\text { Municipal } \\
\text { sewage/The San } \\
\text { Francisco Bay } \\
\text { Area, USA }\end{array}$ & RT-qPCR assay & Ultrafiltration & $\begin{array}{l}\text { Cq values ranged from } 29.5 \text { to } \\
36.2(\sim 2 \text { to } \sim 553 \text { genome } \\
\text { copies } / \mu \mathrm{L} \text { of } \mathrm{RNA}) .\end{array}$ & $\begin{array}{l}\text { - This study sequenced RNA } \\
\text { directly from sewage } \\
\text { collected by municipal } \\
\text { utility districts to generate } \\
\text { complete SARS-CoV-2 } \\
\text { genomes. } \\
\text { - Genomic sequencing can be } \\
\text { used to profile the viral } \\
\text { genetic diversity across } \\
\text { infected communities. }\end{array}$ & $\begin{array}{l}\text { (Crits-Christoph } \\
\text { et al. 2021) }\end{array}$ \\
\hline Sewage pools/China & $\begin{array}{l}\text { Quantitative real-time } \\
\text { reverse transcription } \\
\text { PCR (qRT-PCR) } \\
\text { method }\end{array}$ & Not reported & $\begin{array}{l}\text { Cycle threshold }(\mathrm{Ct}) \text { values of } \\
29.3,30.5,32.4 \text { (inlets of } \\
\text { pre-processing disinfection } \\
\text { pool), and } 33.5 \text { (outlet of }\end{array}$ & $\begin{array}{l}\text { - SARS-Cov-2 is present in the } \\
\text { sewage from pre-processing } \\
\text { disinfection pool of Chinese } \\
\text { hospitals. }\end{array}$ & $\begin{array}{l}\text { (Wang et al. } \\
2020 \mathrm{a})\end{array}$ \\
\hline
\end{tabular}


Table 3 (continued)

\begin{tabular}{|c|c|c|c|c|c|}
\hline $\begin{array}{l}\text { Sample } \\
\text { type/country }\end{array}$ & Quantification method & $\begin{array}{l}\text { Concentration } \\
\text { methods }\end{array}$ & Virus concentration & Key findings & Reference \\
\hline $\begin{array}{l}\text { Urban rivers of } \\
\text { Quito impacted } \\
\text { by the } \\
\text { discharge of } \\
\text { sewage/Ecuador }\end{array}$ & qRT-PCR analysis & $\begin{array}{l}\text { The skimmed milk } \\
\text { flocculation } \\
\text { method }\end{array}$ & $\begin{array}{l}\text { SARS-CoV-2 N1 region: } 3.19 \times \\
10^{6}, 2.84 \times 10^{5} \text {, and } 2.91 \times \\
10^{6} \mathrm{GC} / \mathrm{L} \text {. } \\
\text { SARS-CoV-2 N2 region: } 2.23 \times \\
10^{6}, 2.07 \times 10^{5} \text {, and } 8.55 \times \\
10^{5} \mathrm{GC} / \mathrm{L} .\end{array}$ & $\begin{array}{l}\text { - The SARS-CoV-2 RNA } \\
\text { results demonstrated that } \\
\text { routine disinfection } \\
\text { measures of sewage in the } \\
\text { hospital were sufficient and } \\
\text { the hand hygiene of staff } \\
\text { was effective. } \\
\text { - Viral loads of SARS-CoV-2 } \\
\text { were detected from rivers in } \\
\text { urban streams of Quito. } \\
\text { - -The presence of the virus can } \\
\text { be used as a surveillance tool } \\
\text { for an early warning. } \\
\text { - -A system using main sewage } \\
\text { discharges along the city } \\
\text { helping to control the } \\
\text { pandemic. } \\
\text { - -The method implemented } \\
\text { can be used in other cities } \\
\text { where sewage is not possible } \\
\text { to sample and wastewaters } \\
\text { are discharged to streams or } \\
\text { rivers. }\end{array}$ & $\begin{array}{c}\text { (Guerrero-Latorre } \\
\text { et al. 2020) }\end{array}$ \\
\hline
\end{tabular}

*Considering a positive sample when the cycle threshold $(\mathrm{Ct})$ took place below cycle 40

combined sewer overflows or failures in wastewater infrastructure (Bogler et al. 2020).

Previous studies reported that viral loads of SARS-CoV-2 are present in the water environment. However, some authors did not detect viral RNA, and others provided a method for the rapid assessment of the SARS-CoV-2 transmission risk, as shown in Table 5.

As seen in Table 5, SARS-CoV-2 was detected in surface water. Rimoldi et al. (2020) reported positive results in three rivers in Milan, Italy; however, the concentration of the virus was not measured.

Guerrero-Latorre et al. (2020) found viral loads in the discharge of raw sewage into urban rivers of Quito, Ecuador, and Weidhaas et al. (2021) detected SARS-CoV-2 RNA in small facilities areas, such as Price River WID.

On the other hand, some authors have studied the presence of SARS-CoV-2 in natural water but have not reported the presence of viral concentrations. Haramoto et al. (2020) reported negative results in samples of river water in Japan, and in the results of Desdouits et al. (2021), none of the seawater samples tested positive for SARS-CoV-2 RNA in different areas of France. Samples tested negative can be affected by dilutions made by an incorrect concentration method, or SARS-CoV-2 did not reach the water environment during sampling at significant levels.

Kumar et al. (2021b) and Shutler et al. (2021) reported viral concentrations in natural water bodies through an assessment of the SARS-CoV-2 transmission risk by modifying pollution analysis methods. Viral load values were very different, $<100$ copies/L for small proportions and $>4000$ copies $/ \mathrm{L}$ for large natural water systems, probably due to the large influence of volume.

The detection of SARS-CoV-2 in surface water, such as saltwater and freshwater in rivers, streams, or lakes, has not been sufficiently studied, and the information available is limited, as shown in the table. Moreover, several countries treat their wastewater, so viral loads are considerably lower, although there are also places where wastewater can be discharged into rivers, producing negative impacts due to the presence of human viral pathogens.

The presence and mobility of SARS-CoV-2 in water must be considered because viral RNA copies that are discharged into freshwater and saltwater are a risk of infection for the population in contact with these water bodies (Mahlknecht et al. 2021; Mordecai and Hewson 2020). In addition, studies of water systems could be used to assess the risk of transmission to aquatic and human life and identify countries that are exposed to a high risk of transmission. Additionally, data sources can help to develop viral detection methods to reduce impacts on the environment.

\section{Wastewater}

SARS-CoV-2 has been quantified in wastewater through genomic copying (GC), and the air at wastewater treatment plants (WWTPs) has been monitored to determine its presence 
Table 4 Impacts of COVID-19 in urban-rural areas related to water cycle management

Country/place Key findings $\quad$ Reference

Rural areas and developing countries

Urban-rural areas

Pakistan (urban area)

India (rural area)

Urban areas

Bangladesh and many parts of Africa (rural and peri-urban areas)

Urban and rural areas Jordan, Egypt, or Lebanon (quality).

Urban communities
- Impact of COVID-19 on the SDG number 6: clean water and sanitation due to supply disruptions and inadequate access.

- Rural water supply programs that provide communities with deep boreholes and public hand pumps, sanitation campaigns, and biosand filters for household water treatment.

- During COVID-19 lockdown (i)Venice waters cleared due to fewer boat and tourist activities, and (ii) water utilities from Germany and Austria report that the daily peak of water consumption in the morning is 1.5 to $2 \mathrm{~h}$.

- Cities with high tourist activity will exhibit an important reduction in water consumption.

- Industrial water consumption has decreased, and the agricultural sector has high water demand.

Countries in the Global South (scarcity). Saudi Arabia, - The water scarcity and quality are aggravated by the impacts of COVID-19.

- Competition for water by the different consuming sectors is also happening between the rural and urban areas, mainly in water-scarce economies.

- The COVID-19 pandemic is an accelerator of the existing water crisis.

- COVID-19 exist and can maintain their viability in sewage and the urban water cycle, originating from the fecal discharge of infected patients. Therefore, water contaminated by coronaviruses is a potential vehicle for human exposure.

- The use of chlorine still represents the best economic solution for disinfectant and inactivation in the water of coronavirus.

- The impact of COVID-19 on the informal urban population is a threat to human lives and the health sector, which faces an increasing number of serious cases.

- 34 million people live in urban informal settlements, where water is scarce for basic needs, so government policies have to integrate urban design and water-smart cities for them.

- Covid-19 has impacted SDG 11: make cities and human settlements inclusive, safe, resilient, and sustainable. Water has a direct impact on the resilience and habitability of cities.

- The COVID-19 pandemic has interrupted activities in agriculture and supply chains.

- Water management should focus on the need to guarantee the availability and access to water for subsistence needs and domestic food production.

- The COVID-19 pandemic affects urban water aspects such as engineering processes, sanitary, economic, and social aspects.

- Monitoring of SARS-CoV-2 in human sewage is used to map its spread and scale community outbreaks.

- Sewage tracking from the hospital and pooled human samples indicate the epidemic severity.

- Sewage is a critical tool for human health monitoring due to the COVID-19 pandemic.

- International institutions have to ensure resources were deployed to meet the basic needs of rural communities, such as water to enable hand washing.

- The covid-19 outbreak could still be tackled in rural areas.

- Water systems have perceived positive impacts because of the reduction of pollutant loading from input of vehicle emission, and industries. Also, a reduction in the demand for coliform and biochemical oxygen in rivers and lakes.

- Sewer systems and freshwater sources in hospitals or public places may be contaminated with COVID-19.

France, Italy, Los Angeles, Spain, and Wuhan city of China

Urban cities

Countries, such as China, India, and the USA (urban-rural areas)
- The COVID-19 lockdown has reduced water pollution in many urban cities.

- Due to the clear water and the free movement of wild animals, humans began to feel the recovery of the environment.

- The main impacts of the pandemic for the management of the urban water ination increased due to drugs for COVID-19 treatment, and (iii) water treatment to reduce the transmission of COVID-19 through fecal matter is necessary.

- The presence of COVID-19 in the sewage system provides information about the infection hotspots and efficacy of control and spread patterns through regular testing.

- Controlling the spread of COVID-19 will increase water demand and worsen water quality. cycle are (i) the quality of water resources has improved, (ii) water contam-
(Barbier and Burgess

(Cheval et al. 2020)

(Keulertz et al. 2020)

(Naddeo and Liu

(Neal 2020)

Neal 2020)

(Poch et al. 2020)

(Ranscombe 2020)

(Rashed et al. 2020)

(Rupani et al. 2020)

(Sharifi and

Khavarian-Garmsir 2020)

(Sivakumar 2020) 
Table 4 (continued)

\begin{tabular}{ll}
\hline Country/place & Key findings \\
\hline & The water demands will increase in the domestic, industrial, and recreational \\
& sectors. \\
- & COVID-19 will have serious impacts on water quantity and water quality. \\
- & This pandemic will bring challenges related to water sources, infrastructure for \\
distribution, sewer/drainage structures, wastewater treatment, and disposal.
\end{tabular}

(Medema et al. 2020). Some stages of wastewater treatment processes can generate aerosols, derived from the collision between water sheets in a mixing, aeration, or grease separation stage. Transmission by exposure to wastewater aerosols is possible in wastewater treatment plants (Cruz-Cruz et al. 2020; Gholipour et al. 2021) (Fig 1).

The presence of viral RNA in wastewater has been determined, even when the prevalence of COVID-19 is low, establishing a correlation between the concentration in wastewater and the reported prevalence of COVID-19 (Medema et al. 2020). Monitoring of SARS-CoV-2 in wastewater represents pandemic status, a wastewater-based epidemiological approach (WBE) (W. Ahmed et al. 2021), and has been developed worldwide as an environmental surveillance approach to inform health authority decision-making (Table 6). This epidemiological basis could help to identify specific areas of increased epidemiological activity; however, its use would be limited to cities with a wastewater collection or sewerage system, without clandestine discharges or open drains.

Although the virus has been determined in wastewater and its concentration is correlated with pandemic behavior, recent studies suggest that the risk of accidental occupational exposure to SARS-CoV-2 in raw sewage, through inhalation in a treatment plant environment, is negligible, with less than $0.3 \%$ of the population served by the plant actively infected (Dada and Gyawali 2021). However, other studies indicate that the risk increases as a function of the fraction of the population with an active infection and warn that greater exposure to aerosols may occur if the sewage and wastewater collection system is inadequate. This is a common situation in underdeveloped countries, which may be subject to routes of exposure to the virus by direct ingestion and inhalation of bioaerosol (Zaneti et al. 2021). It is recommended that workers take biosafety measures to reduce risks, such as disinfection of work surfaces with $0.1 \%$ hypochlorite, ventilated work areas, keeping areas free of clutter and personal belongings, and use of long-sleeved gowns, biosafety goggles, and disposable gloves (WHO 2020).

The methodology for SARS-CoV-2 RNA quantification may have some limitations; large differences in catchment size, pipe networks, wastewater characteristics, and subsequently hydraulic retention times can modify the viral concentration (W. Ahmed et al. 2021). Therefore, it is important to use the right concentration method. Viral concentration has been observed to improve with precipitation, filtration, ultrafiltration, and ultracentrifugation (Table 6) (Amoah et al. 2020). The detection of viruses in wastewater and drinking water requires methods that are sensitive, resistant to false-positive results, and must be fast and inexpensive (Lahrich et al. 2021). Viral concentration methods are an essential step to accurately detect SARS-CoV-2 RNA in wastewater (Gonçalves et al. 2021).

The quantification of the virus may vary according to the physicochemical characteristics of the wastewater (Table 6). The concentration of SARS-CoV 2 in the wastewater in GC per liter can be variable between $500 \mathrm{GC} / \mathrm{L}$ and $2200 \mathrm{GC} / \mathrm{mL}$ (Medema et al. 2020; Zhang et al. 2020). According to Medema et al. (2020), this may be related to pandemic status during the analysis. Large particles can protect and contain the virus inside (Wang et al. 2020a), causing unreliable quantification. The sampling method is critical, and $24 \mathrm{~h}$ composite samples may be more reliable in showing the daily average (Sherchan et al. 2020). Sampling protocols should consider the inactivation time of the coronavirus and the effect of storage temperature (Cervantes-Avilés et al. 2021).

Due to the risk of hospital wastewater, treatment with sodium hypochlorite has been proposed (Table 6) at concentrations of $800 \mathrm{~g} / \mathrm{m}^{3}$; under this condition, the virus concentration was 500 $\mathrm{GC} / \mathrm{L}$. To achieve maximum removal, a concentration of 6700 $\mathrm{g} / \mathrm{m}^{3}$ was used. Due to the organic matter load of the wastewater matrix and the high concentration of hypochlorite used, the formation of trichloromethane, tribromomethane, bromodichloromethane, and dibromochloromethane compounds was observed, which represents an environmental risk (Wang et al. 2020b).

\section{Wastewater treatment polluted with SARS-CoV-2}

Removal of the SARS-CoV-2 virus through chlorine disinfection treatment has been evaluated, and the ecological risks of disinfection byproducts need to be carefully considered. Trichloromethane, tribromomethane, bromodichloromethane, and dibromochloromethane concentrations were 332, 1.9, 5.1, and $0.6 \mu \mathrm{g} / \mathrm{L}$ in the effluents, respectively (Table 7). They show high ecological risks and challenge the surrounding environment receiving disinfected medical wastewater, 
Table 5 Detection of SARS-CoV-2 in surface water by several authors

\begin{tabular}{|c|c|c|c|c|c|}
\hline $\begin{array}{l}\text { Sample } \\
\text { type/country }\end{array}$ & $\begin{array}{l}\text { Quantification } \\
\text { method }\end{array}$ & $\begin{array}{l}\text { Concentration } \\
\text { method }\end{array}$ & Virus concentration & Key findings & Reference \\
\hline $\begin{array}{l}\text { River } \\
\text { water/Yamana- } \\
\text { shi, Japan }\end{array}$ & PCR assays & $\begin{array}{l}\text { Electronegative } \\
\text { membrane-vortex } \\
\text { (EMV) and ad- } \\
\text { sorption direct } \\
\text { RNA extraction }\end{array}$ & Not detected & $\begin{array}{l}\text { - None of the river water samples tested positive } \\
\text { for SARS-CoV-2 RNA. }\end{array}$ & $\begin{array}{l}\text { (Haramoto et al. } \\
\text { 2020) }\end{array}$ \\
\hline $\begin{array}{l}\text { Natural water } \\
\text { bodies }\end{array}$ & $\begin{array}{l}\text { Quantitative } \\
\text { microbial risk } \\
\text { assessment } \\
\text { (QMRA) }\end{array}$ & Not applied & $\begin{array}{l}\text { SARS-CoV-2 RNA in receiving water } \\
\text { bodies does not probably exceed }<100 \\
\text { copies/L. } \\
\text { SARS-CoV-2 RNA in receiving water } \\
\text { bodies exceeds }>100 \text { copies/L in an ur- } \\
\text { ban river that consists of a large propor- } \\
\text { tion of treated wastewater from infected } \\
\text { regions. }\end{array}$ & $\begin{array}{l}\text { - The use of QMRA could be useful to manage } \\
\text { the potential risk of SARS-CoV-2 in water } \\
\text { bodies. } \\
\text { - Discharge of untreated wastewater from } \\
\text { combined sewer overflows (CSOs) is very } \\
\text { common in Central Europe (around } 70 \% \text { of } \\
\text { systems are combined sewer systems) and in } \\
\text { the United States. }\end{array}$ & $\begin{array}{c}\text { (Kumar et al. } \\
\text { 2021a) }\end{array}$ \\
\hline $\begin{array}{l}\text { Three river } \\
\text { samples/Milan, } \\
\text { Italy }\end{array}$ & RT-PCR analysis & Not reported & $\begin{array}{l}\text { 14/04/2020: } \\
\text { Vettabbia river }(+) \\
\text { Lambro Meridionale river }(+) \\
\text { Lambro river }(+) \\
\text { 22/04/2020: } \\
\text { Vettabbia river }(-) \\
\text { Lambro Meridionale river }(-) \\
\text { Lambro river }(+)\end{array}$ & $\begin{array}{l}\text { - Positive detection of SARS-CoV-2 RNA in the } \\
\text { receiving rivers in the Milano Metropolitan } \\
\text { Area. } \\
\text { - The presence of the SARS-CoV-2 genome in } \\
\text { rivers indicated the inefficiency of the sewer- } \\
\text { age system of the Milano Metropolitan Area. }\end{array}$ & $\begin{array}{l}\text { (Rimoldi et al. } \\
\text { 2020) }\end{array}$ \\
\hline $\begin{array}{l}\text { Spain, UK, and } \\
\text { Morocco }\end{array}$ & $\begin{array}{r}\text { Relative risk of } \\
\text { transmission }\end{array}$ & Not applied & $\begin{array}{l}\text { Spain: } \\
633 \text { copies per } \\
\quad 100 \mathrm{~mL} \\
\text { UK: } \\
468 \text { copies per } 100 \mathrm{~mL} \\
\text { Morocco: } \\
459 \text { copies per } 100 \mathrm{~mL}\end{array}$ & $\begin{array}{l}\text { - Obtaining a method that quickly assesses the } \\
\text { risk of SARS-CoV- } 2 \text { transmission in water } \\
\text { systems contaminated with feces. } \\
\text { - Interactions between river water and wastewater } \\
\text { spills should be minimized to reduce the risk } \\
\text { of infection. }\end{array}$ & $\begin{array}{l}\text { (Shutler et al. } \\
\text { 2021) }\end{array}$ \\
\hline $\begin{array}{l}\text { Urban rivers of } \\
\text { Quito impacted } \\
\text { by the } \\
\text { discharge of } \\
\text { sewage/ } \\
\text { Ecuador }\end{array}$ & qRT-PCR analysis & $\begin{array}{l}\text { The skimmed milk } \\
\text { flocculation } \\
\text { method }\end{array}$ & $\begin{array}{l}\text { N1 region: } \\
3.19 \times 10^{6}, 2.84 \times 10^{5} \text {, and } 2.91 \times 10^{6} \mathrm{GC} / \mathrm{L} \\
\mathrm{N} 2 \text { region: } \\
2.23 \times 10^{6}, 2.07 \times 10^{5} \text {, and } 8.55 \times 10^{5} \mathrm{GC} / \mathrm{L}\end{array}$ & $\begin{array}{l}\text { - Viral loads of SARS-CoV-2 were detected from } \\
\text { rivers in urban streams of Quito. } \\
\text { - The presence of the virus can be used as a } \\
\text { surveillance tool for an early warning. } \\
\text { - A system using main sewage discharges along } \\
\text { the city helping to control the pandemic. } \\
\text { - The method can be used in other cities where } \\
\text { sewage is not possible to sample and } \\
\text { wastewaters are discharged to streams or } \\
\text { rivers. }\end{array}$ & $\begin{array}{l}\text { (Guerrero-Latorre } \\
\text { et al. 2020) }\end{array}$ \\
\hline $\begin{array}{l}\text { Price river water } \\
\text { improvement } \\
\text { district/Utah }\end{array}$ & $\begin{array}{l}\text { Reverse } \\
\text { transcriptase } \\
\text { quantitative } \\
\text { polymerase } \\
\text { chain reaction } \\
\text { (RT-qPCR) }\end{array}$ & Membrane filtration & $\begin{array}{l}\text { No. of samples/\% positive: } \\
11 / 27 \\
\text { AVG of SARS-CoV- } 2: \\
86 \mathrm{GC} / \mathrm{L}\end{array}$ & $\begin{array}{l}\text { - SARS-CoV-2 RNA was detectable in different } \\
\text { influents during nine weeks. } \\
\text { - SARS-CoV-2 RNA was detectable in small } \\
\text { areas (<100 K people) such as Price River } \\
\text { WID. } \\
\text { - Facilities in areas that serve more than } 100,000 \\
\text { people had higher detection frequencies as } \\
\text { compared to facilities serving smaller } \\
\text { communities. }\end{array}$ & $\begin{array}{l}\text { (Weidhaas et al. } \\
\text { 2021) }\end{array}$ \\
\hline Seawater/France & RT-PCR kit & $\begin{array}{l}\text { Negative-charged } \\
\text { membrane } \\
\text { filtration }(\mathrm{MF}) \\
\text { and } \mathrm{FeCl}_{3} \text { floccu- } \\
\text { lation }(\mathrm{FF})\end{array}$ & $\begin{array}{l}\text { SARS-CoV-2 positive samples: } \\
\text { 0/9 (Normandy area) } \\
\text { 0/22 (Brittany area) } \\
\text { 0/16 (Atlantic area) } \\
\text { 0/9 (Mediterranea area) }\end{array}$ & $\begin{array}{l}\text { - None of the water samples were found } \\
\text { contaminated by SARS-CoV-2. } \\
\text { - SARS-CoV-2 did not reach the French coastal } \\
\text { environment during summer } 2020 \text { at signifi- } \\
\text { cant levels. } \\
\text { - The detection of SARS-CoV-2 in the coastal } \\
\text { environment, using shellfish may help to } \\
\text { monitor the viral diffusion in seaside } \\
\text { communities. }\end{array}$ & $\begin{array}{l}\text { (Desdouits et al. } \\
\text { 2021) }\end{array}$ \\
\hline
\end{tabular}

possessing threats to the ecological system and human health (Wang et al. 2020a).

Conventional wastewater treatment plants (WWTPs) have shown effectiveness in the removal of SARS-CoV-2 (Table 2), which may be related to the removal of solids. These solids can protect the virus, and the treatment must contribute to the removal of solids. Carrillo-Reyes et al. (2021) indicated that the virus may have an affinity for solids.
SARS-CoV-2 concentrations are higher in both primary and waste-activated sludge (Kocamemi et al. 2020a). Virus removal in an aseptic tank was low due to the high concentration of solids; this process does not separate and reduces the solid content (Wang et al. 2020a).

The hydrophobic envelope of the virus could explain the affinity of the virus for the solid matrix of the wastewater (Ahmed et al. 2020c), which is explained by the fact that 


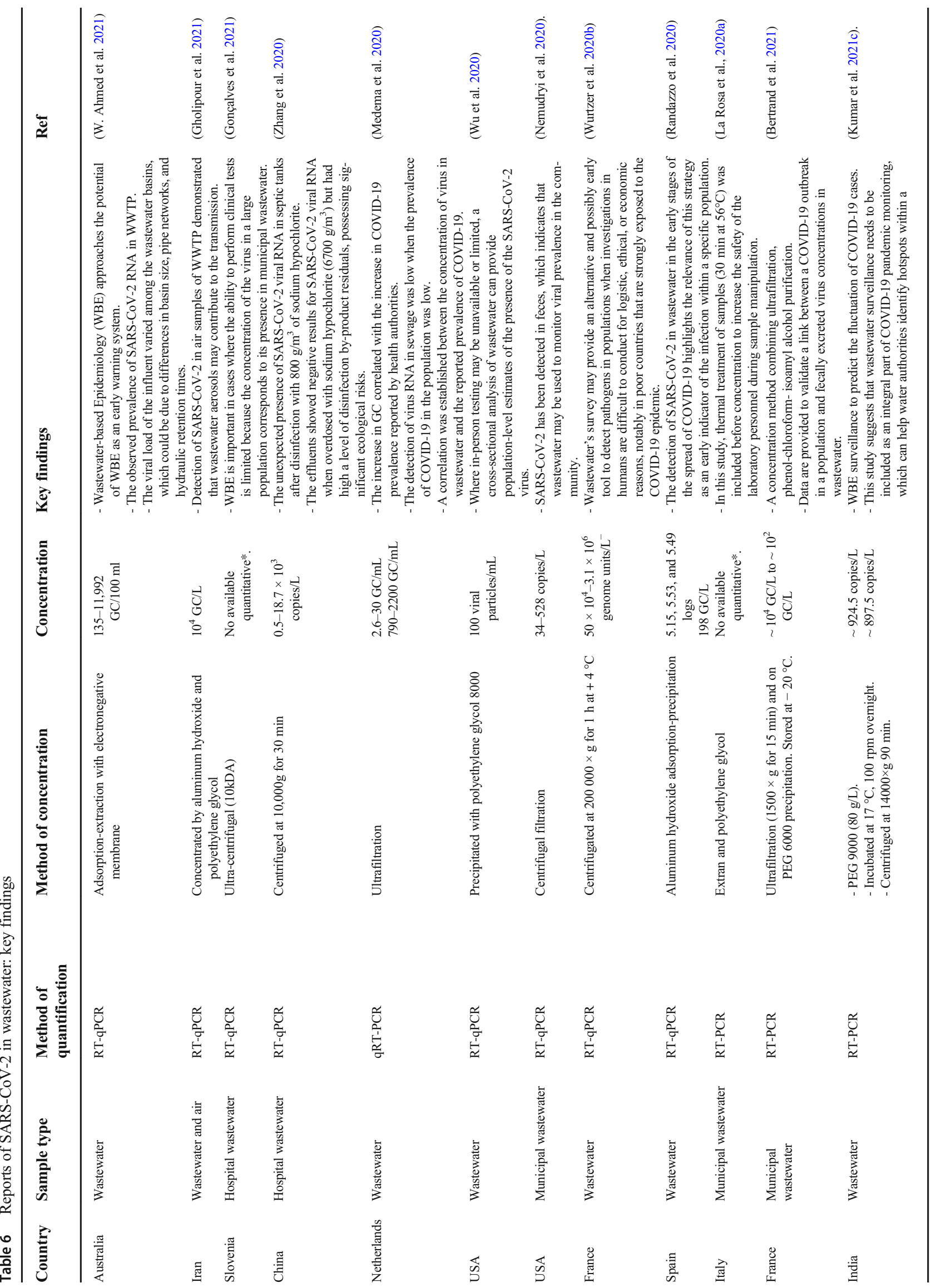


RNA is easier to quantify in the sludge without employing a concentration method, and sludge monitoring has been suggested to serve as an indicator for SARS-CoV-2 surveillance (Carrillo-Reyes et al. 2021). The more efficient the treatment may be in removing solids, the more efficient it will be in removing the virus. The most commonly used methods to improve quantification of the virus in wastewater employ polyethylene glycol to concentrate the viral load (La Rosa, Bonadonna, et al. 2020; Peccia et al. 2020; Zhang et al. 2020).

Virus envelope proteins play a very important role in the process of infection and spread, they can contribute to the strong or weak adhesion of SARS-CoV-2 to its host cell surface, which mainly involves hydrophobic interactions(Jakhmola et al. 2021). These proteins are mostly of a quaternary structure (Duart et al. 2021) and are characterized by hydrophobic interactions (Bhagavan 2002).

The virus concentration can be equal in raw water and primary sludge, and after biological digestion of the sludge, the virus has not been detected (Balboa et al. 2021). Despite the effectiveness of virus removal in raw water and virus denaturation in sludge, chlorination of treated water has been recommended as a final treatment step (Carrillo-Reyes et al. 2021). The combined treatment of thermal hydrolysis and anaerobic digestion prevented the detection of SARS-CoV-2 in sludge effluent of the plant (Balboa et al. 2021).

Although more studies are needed to demonstrate the transmission of the virus via untreated wastewater, the presence of the virus has been demonstrated and poses a risk. Therefore, WWTPs play an important role in controlling the pandemic, as do sewage systems that allow for maximum wastewater collection.

\section{Future trends}

The primary mechanism of virus transmission is person-toperson contact (Rothan and Byrareddy 2020); however, we have discussed other possible routes that represent a risk condition. In the future, it will be important to demonstrate the viral load necessary to generate COVID-19. These secondary mechanisms (Fig. 1) represent a risk, but the particular viral load condition for developing the disease is not clear.

Different efforts to control the spread of COVID-19 will increase the water demand and worsen the water quality, leading to additional challenges in water planning and management (Sivakumar 2020). Further studies are needed to determine the survival of SARS-CoV-2 in the environment, clearer mechanisms of transmissibility through sewage, and the potential to infect humans via the fecal-oral route. (Dhama et al. 2021).

The detection and quantification of the virus have confronted difficulties due to the complex composition of the wastewater. The concentration method is an important factor in determining the virus (La Rosa, Iaconelli, et al. 
Table 7 SARS-CoV-2 removal in wastewater treatment systems

\begin{tabular}{|c|c|c|c|c|c|}
\hline Country & Treatment & Condition treatment & Removal concentration & Key findings & Ref \\
\hline India & $\begin{array}{l}\text { Upflow anaerobic } \\
\text { sludge blanket } \\
\text { (UASB) }\end{array}$ & $\begin{array}{l}\text { Primary treatment: Clarifier } \\
\text { HRT of } 2.5 \mathrm{~h} \\
\text { Secondary treatment: UASB } \\
6 \text { aeration tanks } \\
\text { HRT: } 5 \mathrm{~h} \\
\text { pH: } \sim 7 \text { to } 8.5 \text {. } \\
\text { Sludge thickening unit: } \\
\quad \text { retention time } 20 \text { days } \\
\text { Secondary clarifier: HRT } 2.5 \\
\quad \text { h }\end{array}$ & $\begin{array}{l}\text { Raw wastewater: } 1.8 \times 10^{3} \\
\text { copies/L and } 3.5 \times 10^{3} \\
\text { copies/L } \\
\text { Final effluent: RNA was } \\
\text { not detected at all in the } \\
\text { final effluent }\end{array}$ & $\begin{array}{l}\text { - PEG (polyethylene glycol) method } \\
\text { performed better in removing } \\
\text { materials inhibiting RT-qPCR. } \\
\text { - A conventional treatment system seems } \\
\text { to be effective in reducing the } \\
\text { SARS-CoV-2 genes. }\end{array}$ & $\begin{array}{l}\text { (Kumar et al. } \\
\text { 2020) }\end{array}$ \\
\hline China & $\begin{array}{l}\text { Aseptic tank } \\
\text { chlorination }\end{array}$ & $\begin{array}{l}\text { Sodium hypochlorite was not } \\
\text { regularly added to the final } \\
\text { concentration of } 800 \mathrm{~g} / \mathrm{m}^{3} \\
\text { and it increased to } 6700 \\
\mathrm{~g} / \mathrm{m}^{3} \text {. } \\
1.5 \text {-h contact and the mixing }\end{array}$ & $\begin{array}{l}\text { Raw wastewater: } 7.5 \times \\
10^{3}-14.7 \times 10^{3} \text { copies/L } \\
\text { Final effluent: RNA was } \\
\text { not detected to } 6700 \\
\text { g/m } \mathrm{m}^{3} \text { of sodium } \\
\text { hypochlorite }\end{array}$ & $\begin{array}{l}\text { - Trichloromethane, tribromomethane, } \\
\text { bromodichloromethane, and } \\
\text { dibromochloromethane were } 332,1.9 \text {, } \\
5.1 \text {, and } 0.6 \mu \mathrm{g} / \mathrm{L} \text { in the effluents, re- } \\
\text { spectively. }\end{array}$ & $\begin{array}{l}\text { (Zhang et al. } \\
\text { 2020) }\end{array}$ \\
\hline $\begin{array}{l}\text { United Arab } \\
\text { Emirates } \\
\text { (UAE) }\end{array}$ & $\begin{array}{l}\text { Wastewater } \\
\text { treatment plants } \\
\text { conventional }\end{array}$ & $\begin{array}{l}\text { Preliminary, primary, } \\
\text { secondary } \\
\text { (ASP/clarification), and } \\
\text { tertiary (and filtration, } \\
\text { disinfection, chlorination) }\end{array}$ & $\begin{array}{l}\text { Raw wastewater: } \\
\quad 7.5 \times 10^{2}-3.4 \times 10^{4} \text { gene } \\
\text { copies/L } \\
\text { Final effluent: not detected }\end{array}$ & $\begin{array}{l}\text { - Wastewater treatment technologies } \\
\text { implemented in the UAE are efficient } \\
\text { in the removal of SARS-CoV-2 and } \\
\text { confirm the safety of the treated } \\
\text { re-used water across the country. }\end{array}$ & $\begin{array}{l}\text { (Hasan et al. } \\
\text { 2021) }\end{array}$ \\
\hline México & $\begin{array}{l}\text { Dual } \\
\text { (biofilter/- } \\
\text { activated } \\
\text { sludge). }\end{array}$ & $\begin{array}{l}\text { Coarse and fine screening, } \\
\text { biological treatment and } \\
\text { disinfection process } \\
\text { (chlorinated) }\end{array}$ & $\begin{array}{l}\text { Raw wastewater: } 1.6 \times \\
10^{4}-5.2 \times 10^{4} \text { gene } \\
\text { copies/L } \\
\text { Final effluent: not detected }\end{array}$ & $\begin{array}{l}\text { - Secondary sludge from the WWTP } \\
\text { showed virus RNA levels eight orders } \\
\text { of magnitude higher than in the } \\
\text { influent, suggesting a migration of } \\
\text { genetic material from the liquid to a } \\
\text { solid matrix in the wastewater } \\
\text { treatment process. }\end{array}$ & $\begin{array}{l}\text { (Carrillo-Reyes } \\
\text { et al. 2021) }\end{array}$ \\
\hline México & Activated sludge & $\begin{array}{l}\text { Coarse and fine screening } \\
\text { and biological treatment }\end{array}$ & $\begin{array}{l}\text { Raw wastewater: } 1.8 \times \\
10^{4}-3.8 \times 10^{4} \text { gene } \\
\text { copies/L } \\
\text { Final effluent: not detected }\end{array}$ & $\begin{array}{l}\text { - The detection of virus RNA in the } \\
\text { sludge was determined to be due to } \\
\text { migration of the genetic material, an } \\
\text { affinity of the virus for solids was } \\
\text { observed. }\end{array}$ & $\begin{array}{l}\text { (Carrillo-Reyes } \\
\text { et al. 2021) }\end{array}$ \\
\hline Spain & $\begin{array}{l}\text { WWTP } \\
\text { conventional }\end{array}$ & $\begin{array}{l}\text { Primary sludge } \\
\text { Biologic sludge } \\
\text { Thickened sludge } \\
\text { Digested sludge }\end{array}$ & $\begin{array}{l}\text { In waterline: } \\
\text { Raw wastewater: }<7.5 \times \\
10^{3} \text { copies } / \mathrm{L} \\
\text { Outflow primary: }<7.5 \times \\
10^{3} \text { copies/L } \\
\text { Treated effluent: negative } \\
\text { In sludge line: } \\
\text { Primary sludge: }<7.5 \times 10^{3} \\
\text { copies/L } \\
\text { Biologic sludge: negative } \\
\text { Thickened sludge: } \\
\text { 15 } \times 10^{3}-20 \times 10^{3} \text { copies } / \mathrm{L} \\
\text { Digested sludge: negative } \\
\text { Final effluent: not detected }\end{array}$ & $\begin{array}{l}\text { - The affinity of the SARS-CoV-2 virus } \\
\text { for biosolids was observed to be as- } \\
\text { sociated with sludge currents in } \\
\text { WWTPs. } \\
\text { - The combined treatment of thermal } \\
\text { hydrolysis and anaerobic digestion } \\
\text { prevented the detection of } \\
\text { SARS-CoV-2 in sludge leaving the } \\
\text { plant. }\end{array}$ & $\begin{array}{l}\text { (Balboa et al. } \\
\text { 2021) }\end{array}$ \\
\hline Turkey & Activated sludge & $\begin{array}{l}\text { Primary sedimentation tanks. } \\
\text { Waste activated sludge } \\
\text { (WAS) }\end{array}$ & $\begin{array}{l}1.17 \times 10^{4} \text { to } 4.02 \times 10^{4} \\
\text { viruses per liter. } \\
\text { Final effluent: not } \\
\text { determined }\end{array}$ & $\begin{array}{l}\text { - In this study, it was observed that } \\
\text { SARS-CoV-2 virus concentrations } \\
\text { were higher in both primary and acti- } \\
\text { vated sludge. }\end{array}$ & $\begin{array}{l}\text { (Kocamemi } \\
\text { et al., 2020a) }\end{array}$ \\
\hline
\end{tabular}

2020a; Carrillo-Reyes et al. 2021; Dhama et al. 2021). Therefore, more sensitive, easy to perform, accessible, and economical techniques are needed to further monitor the pandemic and allow sanitary control to ensure public health. Devices have been suggested for trace detection of SARS-CoV-2 in water. One of the main challenges in the detection/quantification of SARS-CoV-2 in wastewater samples is to generate optimized and standardized protocols (Kitajima et al. 2020), where the risk of transmission is high, as shown in Fig. 4.

WWTPs have shown effectiveness in virus removal (Arora et al. 2020; Jiao Wang et al. 2020a); however, more knowledge is needed about virus sharing through the different stages of the treatments to more clearly determine the most effective removal or denaturation method against the virus.

Disinfection methods used in the drinking water treatment process highly inactivate and efficiently destroy SARS-CoV-2 in water (Tran et al. 2021). However, there is a need to investigate and improve the performance of disinfection technologies to be adopted for the inactivation of SARS-CoV-2 in municipal and hospital wastewater to reduce the related risk. (Mandal et al. 2020; Tran et al. 2021).

The studies compiled in this review are solid antecedents that demonstrate the presence of the SARS-CoV-2 in natural 

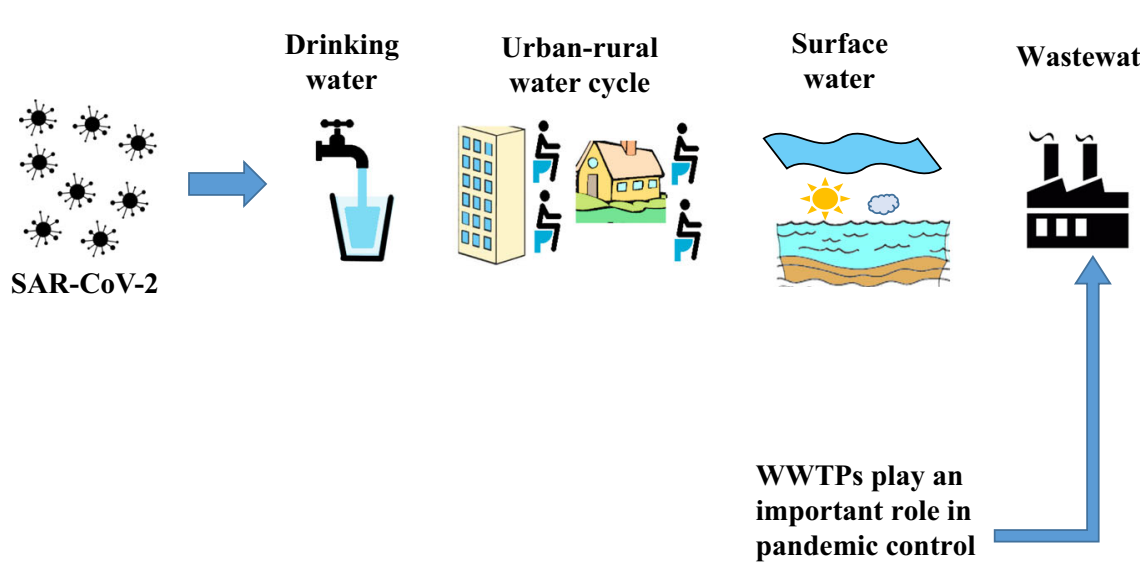

Studies reported SAR-CoV-2

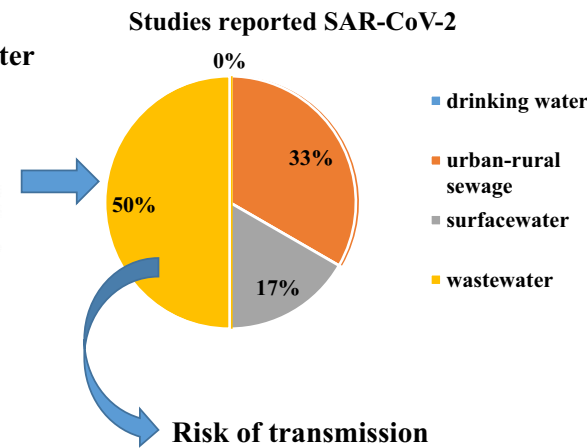

important role in

pandemic control

Fig. 4 Potential risk of transmission of SARS-CoV-2 in water

water and wastewater. Some data found, such as the study areas and concentrations of viral loads, would help to quickly relate the presence of the virus in water with the epidemiological and sanitary situation in the future, which could determine the economic and social factors that they intervene in the duration of the disease in different rural or urban communities

Identifying those geographic areas that report the presence of SARS-CoV-2 in water could support future research to predict or control re-outbreaks in surrounding areas. In Italy, viral loads were detected in contiguous rivers and traveled through densely populated areas near the Milan metropolitan area last year and then a re-outbreak occurred in the neighboring city (Lazio).

The need for further research to establish the behavior of the SARS-CoV-2 virus in aquatic systems is a priority to establish efficient methods to concentrate and detect enveloped viruses (and coronavirus in particular) from water matrices and the estimation of the survival of these viruses in natural conditions, at different temperatures and in different types of water. Additionally, the information collected on SARS-CoV-2 in this review aims to facilitate ideas that improve the monitoring of COVID-19 in natural and wastewater in future studies, which would allow investigating the development of the disease in the population. This information would help to determine the stability of the virus in water bodies and to know its possible dynamics in space and time.

The findings discussed in this review would generate options that mitigate the presence of the virus and with it its transmission in drinking water, natural water, and wastewater. Finally, these findings could be used to develop new preventive measures, in addition to healthy distance, temperature measurement, and the use of antibacterial gel, related to the pathways of spread of SARS-CoV-2 in water.

\section{Conclusions}

After reviewing 169 references, it was possible to analyze the characteristics of the coronavirus, its transfer routes, detection methods, and its impact on drinking water, surface water, wastewater, and systems that are effective for wastewater treatment.

The presence of SARS-CoV-2 has been demonstrated in the water cycle in both urban and rural areas. One of the routes of transmission of the virus is through the sewage system of domestic origin, i.e., gray water, sewage, soaps and detergents, and toilet paper.

The monitoring of SARS-CoV-2 in wastewater can be a tool that can monitor the behavior of the pandemic. Conventional treatment systems are effective in removing the virus, and a relationship between solid removal and viral load has been observed. WWTPs play an important role in pandemic control.

The transmission of SARS-CoV-2 may be greater in rural areas. Public policies surrounding the urban-rural water cycle have been exposed as deficient and bad in several countries, mainly third world countries.

Some studies have reported the presence of water pathogens including viruses in drinking water. However, SARS-CoV-2 has not yet been found in any drinking water facilities, and it is safe to comment that the risk to drinking water supplies is low.

There is still little information available regarding the existence of SARS-CoV-2 in surface waters; however, more study is needed as its detection in different bodies of water, which are usually in direct contact, is important. These studies should include different natural ecosystems, both terrestrial and aquatic.

The presence of SARS-CoV-2 in surface water should be further studied to determine whether its transmission to different living beings, including humans, is possible and whether it is important to reduce or eradicate possible loads of viruses found in these waters.

Finally, future trends focus on the scope of the present information collected by several authors about the impact of coronavirus SARS-CoV-2 in water to answer the question of how this review could guide future research. 
Abbreviations $A S P$, Activated sludge process; $A R D S$, Acute respiratory distress syndrome; $A L G$, Alum coagulant; $A C E 2$, Angiotensin-converting enzyme 2; $B D D$, Boron-doped diamond; $B B D / S i$, Boron-doped diamond/ silicon; $C S$, Coagulation-sedimentation; $C S O s$, Combined sewer overflows; $c D N A$, Complementary DNA; COVID-19, Coronavirus disease 2019; $C$, Cycle threshold; DIC, Disseminated intravascular coagulation; $E C-E O$, Electrocoagulation-electro-oxidation; $E M V$, Electronegative membrane-vortex; $M S 2$ virus, Escherichia virus $\mathrm{MS} 2 ; \mathrm{FF}, \mathrm{FeCl}_{3}$ flocculation; GI qPCR, Gastrointestinal qPCR; $G C / L$, Genomic copies per liter; $H A V$, Hepatitis A virus; $H E V$, Hepatitis E virus; $H E V$ - $p 6$, Hepatitis E virus strain Kernow (clone P6); AdHu5-GFP, Human adenovirus type 5-green fluorescent protein; $\mathrm{HCOVs}$, Human coronaviruses; Hep $\mathrm{G} 2 / \mathrm{C} 3 \mathrm{~A}$, Human hepatocellular carcinoma cells; $H R T$, Hydraulic retention time; IFA, Immunofluorescence assay; $M F$, Microfiltration; MERS-CoV, Middle East respiratory syndrome coronavirus; $M N V-1$, Murine norovirus 1; $P M M o V$, Pepper mild mottle virus; $P E G$, Polyethylene glycol; $P A X$, Prepolymerized aluminum coagulant; $Q M R A$, Quantitative microbial risk assessment; $q P C R$, Quantitative polymerase chain reaction; $R S F$, Rapid sand filtration; $R T-P C R$, Reverse transcription-polymerase chain reaction; $R N A$, Ribonucleic acid; $S A R S-C O V-2$, Severe acute respiratory syndrome coronavirus 2; SDG, Sustainable development goals; TMPRSS2, Transmembrane serine protease 2; $U F$, Ultrafiltration; $U A E$, United Arab Emirates; $U A S B$, Upflow anaerobic sludge blanket; $\phi X 174$ virus, Virus that infects the bacterium E. coli; WAS, Waste-activated sludge; WWTP, Wastewater treatment plants; WBE, Wastewater-based epidemiology; WID, Water improvement district; $W H O$, World Health Organization

Authors' contributions RGN: devised the project, the main conceptual ideas, conducting a research and investigation process. ILH: devised the project, the main conceptual ideas, acquisition of the financial support for the project leading to this publication. LACS: supervised the project, revised it critically for important intellectual content. All authors provided critical feedback and helped shape the research, analysis, and manuscript. All authors read and approved the final manuscript.

Funding The authors would like to acknowledge the support of CONACYT for the scholarship (CVU: 863657) and thank COMECYT for the chair number CAT2021-0016.

Data availability The datasets used and/or analyzed during the current study are available from the corresponding author on reasonable request.

\section{Declarations}

Competing interests The authors declare no competing interests.

\section{References}

Adelodun B, Ajibade FO, Ibrahim RG, Bakare HO, Choi K-S (2020) Snowballing transmission of COVID-19 (SARS-CoV-2) through wastewater: any sustainable preventive measures to curtail the scourge in low-income countries? Sci Total Environ 742:140680. https://doi.org/10.1016/j.scitotenv.2020.140680

Adelodun B, Ajibade FO, Ighalo JO, Odey G, Ibrahim RG, Kareem KY, Bakare HO, Tiamiyu AO, Ajibade TF, Abdulkadir TS, Adeniran KA, Choi KS (2021) Assessment of socioeconomic inequality based on virus-contaminated water usage in developing countries: A review. Environ Res 192:110309. https://doi.org/10.1016/j.envres. 2020.110309

Ahmed J, Wong LP, Chua YP, Yasmin A, Channa N, VanDerslice JA (2020a) Estimation of hepatitis a virus infection prevalence through drinking water supply of primary schools of Sindh, Pakistan. Hepat Mon 20(5). https://doi.org/10.5812/hepatmon.98412

Ahmed W, Angel N, Edson J, Bibby K, Bivins A, O’Brien JW, Choi PM, Kitajima M, Simpson SL, Li J, Tscharke B, Verhagen R, Smith WJM, Zaugg J, Dierens L, Hugenholtz P, Thomas KV, Mueller JF (2020b) First confirmed detection of SARS-CoV-2 in untreated wastewater in Australia: A proof of concept for the wastewater surveillance of COVID-19 in the community. Sci Total Environ 728: 138764. https://doi.org/10.1016/j.scitotenv.2020.138764

Ahmed W, Bertsch PM, Bivins A, Bibby K, Farkas K, Gathercole A, Haramoto E, Gyawali P, Korajkic A, McMinn BR, Mueller JF, Simpson SL, Smith WJM, Symonds EM, Thomas KV, Verhagen R, Kitajima M (2020c) Comparison of virus concentration methods for the RT-qPCR-based recovery of murine hepatitis virus, a surrogate for SARS-CoV-2 from untreated wastewater. Sci Total Environ 739(June):139960. https://doi.org/10.1016/j.scitotenv.2020.139960

Ahmed W, Tscharke B, Bertsch PM, Bibby K, Bivins A, Choi P, Clarke L, Dwyer J, Edson J, Nguyen TMH, O'Brien JW, Simpson SL, Sherman P, Thomas KV, Verhagen R, Zaugg J, Mueller JF (2021) SARS-CoV-2 RNA monitoring in wastewater as a potential early warning system for COVID-19 transmission in the community: a temporal case study. Sci Total Environ 761:144216. https://doi.org/ 10.1016/j.scitotenv.2020.144216

Al Huraimel K, Alhosani M, Kunhabdulla S, Stietiya MH (2020) SARSCoV-2 in the environment: modes of transmission, early detection and potential role of pollutions. Sci Total Environ 744:140946. https://doi.org/10.1016/j.scitotenv.2020.140946

Amirian ES (2020) Potential fecal transmission of SARS-CoV-2: Current evidence and implications for public health. Int J Infect Dis 95:363370. https://doi.org/10.1016/j.ijid.2020.04.057

Amoah ID, Kumari S, Bux F (2020) Coronaviruses in wastewater processes: Source, fate and potential risks. Environ Int 143(May): 105962. https://doi.org/10.1016/j.envint.2020.105962

Anayah F, Al-Khatib IA, Hejaz B (2021) Assessment of water and sanitation systems at Palestinian healthcare facilities: pre- and postCOVID-19. Environ Monit Assess 193(1):41. https://doi.org/10. 1007/s10661-020-08791-4

Arnaout R, Lee RA, Lee GR, Callahan C, Yen CF, Smith KP, Arora R, Kirby JE (2020) SARS-CoV2 testing: the limit of detection matters. BioRxiv. https://doi.org/10.1101/2020.06.02.131144

Arora S, Nag A, Sethi J, Rajvanshi J, Saxena S, Shrivastava SK, Gupta AB (2020) Sewage surveillance for the presence of SARS-CoV-2 genome as a useful wastewater based epidemiology (WBE) tracking tool in India. Water Sci Technol 82(12):2823-2836. https://doi.org/ $10.2166 /$ wst.2020.540

Astuti I, Ysrafil (2020) Severe acute respiratory syndrome coronavirus 2 (SARS-CoV-2): an overview of viral structure and host response. Diabetes Metab Syndr Clin Res Rev 14(4):407-412. https://doi.org/ 10.1016/j.dsx.2020.04.020

Balacco G, Totaro V, Iacobellis V, Manni A, Spagnoletta M, Piccinni AF (2020) Influence of COVID-19 spread on water drinking demand: the case of Puglia Region (Southern Italy). Sustainability 12(15): 5919. https://doi.org/10.3390/su12155919

Balboa S, Mauricio-Iglesias M, Rodriguez S, Martínez-Lamas L, Vasallo FJ, Regueiro B, Lema JM (2021) The fate of SARS-COV-2 in WWTPS points out the sludge line as a suitable spot for detection of COVID-19. Sci Total Environ 772:145268. https://doi.org/10. 1016/j.scitotenv.2021.145268

Banerjee A, Pasea L, Harris S, Gonzalez-Izquierdo A, Torralbo A, Shallcross L, Noursadeghi M, Pillay D, Sebire N, Holmes C, Pagel C, Wong WK, Langenberg C, Williams B, Denaxas S, Hemingway H (2020) Estimating excess 1-year mortality associated with the COVID-19 pandemic according to underlying conditions and age: a population-based cohort study. Lancet 395(10238):17151725. https://doi.org/10.1016/S0140-6736(20)30854-0 
Barbier EB, Burgess JC (2020) Sustainability and development after COVID-19. World Dev 135:105082. https://doi.org/10.1016/j. worlddev.2020.105082

Bar-On YM, Flamholz A, Phillips R, Milo R (2020) SARS-CoV-2 (COVID-19) by the numbers. ELife 9:1-15. https://doi.org/10. 7554/eLife.57309

Bar-OrI, Yaniv K, Shagan M, Ozer E, Erster O, Mendelson E, Mannasse B, Shirazi R, Kramarsky-Winter E, Nir O, Abu-Ali H, Ronen Z, Rinott E, Lewis YE, Friedler E, Bitkover E, Paitan Y, Berchenko Y, \& Kushmaro A (2020). Regressing SARS-CoV-2 sewage measurements onto COVID-19 burden in the population: a proof-ofconcept for quantitative environmental surveillance. MedRxiv, 111. https://doi.org/10.1101/2020.04.26.20073569

Belete TM (2020) A review on promising vaccine development progress for COVID-19 disease. Vacunas (English Edition) 21(2):121-128. https://doi.org/10.1016/j.vacune.2020.10.009

Bertrand I, Challant J, Jeulin H, Hartard C, Mathieu L, Lopez S, Schvoerer E, Courtois S, Gantzer C (2021) Epidemiological surveillance of SARS-CoV-2 by genome quantification in wastewater applied to a city in the northeast of France: comparison of ultrafiltration- and protein precipitation-based methods. Int J Hyg Environ Health 233(January):113692. https://doi.org/10.1016/j. ijheh.2021.113692

Bhagavan NV (2002). Three-dimensional structure of proteins. In Medical Biochemistry (Vol. 24, Issue 9, pp. 51-65). Elsevier. https://doi.org/10.1016/B978-012095440-7/50006-8

Bhowmick GD, Dhar D, Nath D, Ghangrekar MM, Banerjee R, Das S, Chatterjee J (2020) Coronavirus disease 2019 (COVID-19) outbreak: some serious consequences with urban and rural water cycle. Npj Clean Water 3(1):32. https://doi.org/10.1038/s41545-0200079-1

Bilal M, Nazir MS, Rasheed T, Parra-Saldivar R, Iqbal HMN (2020) Water matrices as potential source of SARS-CoV-2 transmission an overview from environmental perspective. Case Stud Chem Environ Eng 2(June):100023. https://doi.org/10.1016/j.cscee.2020. 100023

Bogler A, Packman A, Furman A, Gross A, Kushmaro A, Ronen A, Dagot C, Hill C, Vaizel-Ohayon D, Morgenroth E, Bertuzzo E, Wells G, Kiperwas HR, Horn H, Negev I, Zucker I, Bar-Or I, Moran-Gilad J, Balcazar JL et al (2020) Rethinking wastewater risks and monitoring in light of the COVID-19 pandemic. Nat Sustain 3 (12):981-990. https://doi.org/10.1038/s41893-020-00605-2

Boulter N, Suarez FG, Schibeci S, Sunderland T, Tolhurst O, Hunter T, Hodge G, Handelsman D, Simanainen U, Hendriks E, Duggan K (2016) A simple, accurate and universal method for quantification of PCR. BMC Biotechnol 16(1):27. https://doi.org/10.1186/s12896016-0256-y

Bouseettine R, Hassou N, Bessi H, \& Ennaji MM (2019). Waterborne transmission of enteric viruses and their impact on public health. In Emerging and reemerging viral pathogens: Volume 1: Fundamental and basic virology aspects of human, animal and plant pathogens (pp. 907-932). Elsevier. https://doi.org/10.1016/B978-0-12819400-3.00040-5

Bridle H (2014). Overview of waterborne pathogens. In Waterborne Pathogens (pp. 9-40). Elsevier. https://doi.org/10.1016/B978-0444-59543-0.00002-5

Cahill N, Morris D (2020) Recreational waters - a potential transmission route for SARS-CoV-2 to humans? Sci Total Environ 740:140122. https://doi.org/10.1016/j.scitotenv.2020.140122

Carraturo F, Del Giudice C, Morelli M, Cerullo V, Libralato G, Galdiero E, Guida M (2020) Persistence of SARS-CoV-2 in the environment and COVID-19 transmission risk from environmental matrices and surfaces. Environ Pollut 265:115010. https://doi.org/10.1016/j. envpol.2020.115010

Carrillo-Reyes J, Barragán-Trinidad M, Buitrón G (2021) Surveillance of SARS-CoV-2 in sewage and wastewater treatment plants in Mexico.
J Water Process Eng 40(September):101815. https://doi.org/10. 1016/j.jwpe.2020.101815

Celis JE, Espejo W, Paredes-Osses E, Contreras SA, Chiang G, Bahamonde P (2021) Plastic residues produced with confirmatory testing for COVID-19: classification, quantification, fate, and impacts on human health. Sci Total Environ 760:144167. https://doi. org/10.1016/j.scitotenv.2020.144167

Cervantes-Avilés P, Moreno-Andrade I, Carrillo-Reyes J (2021) Approaches applied to detect SARS-CoV-2 in wastewater and perspectives post-COVID-19. J Water Process Eng 40(December 2020):101947. https://doi.org/10.1016/j.jwpe.2021.101947

Chen M, Zeng J, Liu X, Sun G, Gao Y, Liao J, Yu J, Luo X, Qi H (2020) Changes in physiology and immune system during pregnancy and coronavirus infection: a review. Eur J Obstet Gynecol Reprod Biol 255:124-128. https://doi.org/10.1016/j.ejogrb.2020.10.035

Chen L, Deng Y, Dong S, Wang H, Li P, Zhang H, Chu W (2021) The occurrence and control of waterborne viruses in drinking water treatment: a review. Chemosphere 281:130728. https://doi.org/10.1016/ j.chemosphere.2021.130728

Cheval S, Mihai Adamescu C, Georgiadis T, Herrnegger M, Piticar A, Legates DR (2020) Observed and potential impacts of the COVID19 pandemic on the environment. Int J Environ Res Public Health 17 (11):4140. https://doi.org/10.3390/ijerph17114140

Chida AS, Goldstein JM, Lee J, Tang X, Bedi K, Herzegh O, Moon JL, Petway D, Bagarozzi DA, Hughes LJ (2021) Comparison of Zika virus inactivation methods for reagent production and disinfection methods. J Virol Methods 287(October 2020):114004. https://doi. org/10.1016/j.jviromet.2020.114004

Clay JM, Parker MO (2020) Alcohol use and misuse during the COVID19 pandemic: a potential public health crisis? Lancet Public Health 5 (5):e259. https://doi.org/10.1016/S2468-2667(20)30088-8

Corman VM, Landt O, Kaiser M, Molenkamp R, Meijer A, Chu DKW, Bleicker T, Brünink S, Schneider J, Schmidt ML, Mulders DGJC, Haagmans BL, van der Veer B, van den Brink S, Wijsman L, Goderski G, Romette J-L, Ellis J, Zambon M, ... Drosten C (2020). Detection of 2019 novel coronavirus (2019-nCoV) by realtime RT-PCR. Eurosurveillance, 25(3). https://doi.org/10.2807/ 1560-7917.ES.2020.25.3.2000045

Crits-Christoph A, Kantor RS, Olm MR, Whitney ON, Al-Shayeb B, Lou YC, Flamholz A, Kennedy LC, Greenwald H, Hinkle A, Hetzel J, Spitzer S, Koble J, Tan A, Hyde F, Schroth G, Kuersten S, Banfield JF, Nelson KL (2021) Genome sequencing of sewage detects regionally prevalent SARS-CoV-2 variants. MBio 12(1):1-9. https:// doi.org/10.1128/mBio.02703-20

Cruz-Cruz C, Rodríguez-Dozal S, Cortez-Lugo M, Ovilla-Muñoz M, Carnalla-Cortés M, Sánchez-Pájaro A, Schilmann A (2020) Revisión rápida: monitoreo de la presencia e infectividad del virus SARS-CoV-2 y otros coronavirus en aguas residuales. Salud Publica Mex 63(1):109-119. https://doi.org/10.21149/11783

Cuevas-Ferrando E, Pérez-Cataluña A, Allende A, Guix S, Randazzo W, Sánchez G (2021) Recovering coronavirus from large volumes of water. Sci Total Environ 762:143101. https://doi.org/10.1016/j. scitotenv.2020.143101

Cullen W, Gulati G, Kelly BD (2020) Mental health in the COVID-19 pandemic. QJM : Monthly Journal of the Association of Physicians 113(5):311-312. https://doi.org/10.1093/qjmed/hcaa110

Cunningham JW, Vaduganathan M, Claggett BL, Jering KS, Bhatt AS, Rosenthal N, Solomon SD (2020) Clinical outcomes in young US adults hospitalized with COVID-19. JAMA Intern Med, 8-10. https://doi.org/10.1001/jamainternmed.2020.5313

Dada AC, Gyawali P (2021) Quantitative microbial risk assessment (QMRA) of occupational exposure to SARS-CoV-2 in wastewater treatment plants. Sci Total Environ 763:142989. https://doi.org/10. 1016/j.scitotenv.2020.142989

Deiana M, Mori A, Piubelli C, Scarso S, Favarato M, Pomari E (2020) Assessment of the direct quantitation of SARS-CoV-2 by droplet 
digital PCR. Sci Rep 10(1):1-7. https://doi.org/10.1038/s41598020-75958-x

Desdouits M, Piquet J, Wacrenier C, Le Mennec C, Parnaudeau S, Jousse S, Rocq S, Bigault L, Contrant M, Garry P, Chavanon F, Gabellec R, Lamort L, Lebrun L, Le Gall P, Meteigner C, Schmitt A, Seugnet JL, Serais O et al (2021) Can shellfish be used to monitor SARSCoV-2 in the coastal environment? Sci Total Environ 778(January): 146270. https://doi.org/10.1016/j.scitotenv.2021.146270

Dhama K, Patel SK, Yatoo MI, Tiwari R, Sharun K, Dhama J, Natesan S, Malik YS, Singh KP, \& Harapan H (2021). SARS-CoV-2 existence in sewage and wastewater: a global public health concern? In Journal of Environmental Management (Vol. 280). Academic Press. https://doi.org/10.1016/j.jenvman.2020.111825

Di Santo SG, Franchini F, Filiputti B, Martone A, Sannino S (2020) The effects of COVID-19 and quarantine measures on the lifestyles and mental health of people over 60 at increased risk of dementia. Front Psychiatry 11(October):1-14. https://doi.org/10.3389/fpsyt.2020. 578628

Dong BB, Xu CL, Dong LB, Cheng HJ, Yang L, Zou SM, Chen M, Bai T, Zhang Y, Gao RB, Li XD, Shi JH, Yuan H, Yang J, Chen T, Zhu Y, Xiong Y, Yang S, Shu YL (2013) A novel reassortant H3N8 influenza virus isolated from drinking water for duck in a domestic duck farm in Poyang Lake Area. Biomed Environ Sci 26(7):546551. https://doi.org/10.3967/0895-3988.2013.07.005

Drexler JF, Corman VM, Drosten C (2014) Ecology, evolution and classification of bat coronaviruses in the aftermath of SARS. Antivir Res 101(1):45-56. https://doi.org/10.1016/j.antiviral.2013.10.013

Duart G, García-Murria MJ, Mingarro I (2021) The SARS-CoV-2 envelope (E) protein has evolved towards membrane topology robustness. Biochim Biophys Acta Biomembr 1863(7):183608. https:// doi.org/10.1016/j.bbamem.2021.183608

Emelko MB, Schmidt PJ, Borchardt MA (2019) Confirming the need for virus disinfection in municipal subsurface drinking water supplies. Water Res 157:356-364. https://doi.org/10.1016/j.watres.2019.03. 057

Eslami H, \& Jalili M (2020). The role of environmental factors to transmission of SARS-CoV-2 (COVID-19). In AMB Express (Vol. 10, Issue 1). https://doi.org/10.1186/s13568-020-01028-0

Fegert JM, Vitiello B, Plener PL, Clemens V (2020) Challenges and burden of the Coronavirus 2019 (COVID-19) pandemic for child and adolescent mental health: a narrative review to highlight clinical and research needs in the acute phase and the long return to normality. Child Adolesc Psychiatry Ment Health 14(1):1-11. https://doi. org/10.1186/s13034-020-00329-3

Fehr AR, Perlman S (2015) Coronaviruses: an overview of their replication and pathogenesis. In: In Coronaviruses: methods and protocols. Springer, New York, pp 1-23. https://doi.org/10.1007/978-1-49392438-7 1

Feroz AS, Ali NA, Ali NA, Feroz R, Meghani SN, Saleem S (2020) Impact of the COVID-19 pandemic on mental health and wellbeing of communities: an exploratory qualitative study protocol. BMJ Open 10(12):8-11. https://doi.org/10.1136/bmjopen-2020041641

Fiksdal L, Leiknes TO (2006) The effect of coagulation with MF/UF membrane filtration for the removal of virus in drinking water. J Membr Sci 279(1-2):364-371. https://doi.org/10.1016/j.memsci. 2005.12.023

Garcia LAT, Barardi CRM (2019) Performance of a storage tank coupled with UV light on enteric virus inactivation in drinking water. Water Sci Technol Water Supply 19(4). https://doi.org/10.2166/ws.2018. 161

García-Ávila F, Valdiviezo-Gonzales L, Cadme-Galabay M, GutiérrezOrtega H, Altamirano-Cárdenas L, Arévalo CZ, Flores del Pino L (2020) Considerations on water quality and the use of chlorine in times of SARS-CoV-2 (COVID-19) pandemic in the community.
Case Stud Chem Environ Eng 2:100049. https://doi.org/10.1016/j. cscee. 2020.100049

Gholipour S, Mohammadi F, Nikaeen M, Shamsizadeh Z, Khazeni A, Sahbaei Z, Mousavi SM, Ghobadian M, Mirhendi H (2021) COVID-19 infection risk from exposure to aerosols of wastewater treatment plants. Chemosphere 273. https://doi.org/10.1016/j. chemosphere.2021.129701

Gonçalves J, Koritnik T, Mioč V, Trkov M, Bolješič M, Berginc N, Prosenc K, Kotar T, Paragi M (2021) Detection of SARS-CoV-2 RNA in hospital wastewater from a low COVID-19 disease prevalence area. Sci Total Environ 755:143226. https://doi.org/10.1016/j. scitotenv.2020.143226

Guerrero-Latorre L, Gonzales-Gustavson E, Hundesa A, Sommer R, Rosina G (2016) UV disinfection and flocculation-chlorination sachets to reduce hepatitis E virus in drinking water. Int J Hyg Environ Health 219(4-5):405-411. https://doi.org/10.1016/j.ijheh.2016.04. 002

Guerrero-Latorre L, Ballesteros I, Villacrés-Granda I, Granda MG, Freire-Paspuel B, Ríos-Touma B (2020) SARS-CoV-2 in river water: implications in low sanitation countries. Sci Total Environ 743: 140832. https://doi.org/10.1016/j.scitotenv.2020.140832

Gwenzi W (2021) Leaving no stone unturned in light of the COVID-19 faecal-oral hypothesis? A water, sanitation and hygiene (WASH) perspective targeting low-income countries. Sci Total Environ 753:141751. https://doi.org/10.1016/j.scitotenv.2020.141751

Haramoto E, Kitajima M, Hata A, Torrey JR, Masago Y, Sano D, Katayama H (2018) A review on recent progress in the detection methods and prevalence of human enteric viruses in water. Water Res 135:168-186. https://doi.org/10.1016/j.watres.2018.02.004

Haramoto E, Malla B, Thakali O, Kitajima M (2020) First environmental surveillance for the presence of SARS-CoV-2 RNA in wastewater and river water in Japan. Sci Total Environ 737:140405. https://doi. org/10.1016/j.scitotenv.2020.140405

Hasan SW, Ibrahim Y, Daou M, Kannout H, Jan N, Lopes A, Alsafar H, Yousef AF (2021) Detection and quantification of SARS-CoV-2 RNA in astewater and treated effluents: surveillance of COVID-19 epidemic in the United Arab Emirates. Sci Total Environ 764: 142929. https://doi.org/10.1016/j.scitotenv.2020.142929

Heffron J, Ryan DR, Mayer BK (2019) Sequential electrocoagulationelectrooxidation for virus mitigation in drinking water. Water Res 160:435-444. https://doi.org/10.1016/j.watres.2019.05.078

Hennechart-Collette C, Dehan O, Fraisse A, Martin-Latil S, Perelle S (2020) Evaluation of three different filters and two methods for recovering viruses from drinking water. J Virol Methods 284: 113939. https://doi.org/10.1016/j.jviromet.2020.113939

Hoseinzadeh E, Javan S, Farzadkia M, Mohammadi F, Hossini H, Taghavi M (2020) An updated min-review on environmental route of the SARS-CoV-2 transmission. Ecotoxicol Environ Saf 202 (May):111015. https://doi.org/10.1016/j.ecoenv.2020.111015

Ibrahim Y, Ouda M, Kadadou D, Banat F, Naddeo V, Alsafar H, Yousef AF, Barceló D, \& Hasan SW (2021). Detection and removal of waterborne enteric viruses from wastewater: a comprehensive review. In Journal of Environmental Chemical Engineering (Vol. 9, Issue 4, p. 105613). Elsevier Ltd. https://doi.org/10.1016/j.jece. 2021.105613

Jakhmola S, Indari O, Kashyap D, Varshney N, Das A, Manivannan E, Jha HC (2021) Mutational analysis of structural proteins of SARSCoV-2. Heliyon 7(3):e06572. https://doi.org/10.1016/j.heliyon. 2021.e06572

Kassem II, Jaafar H (2020) The potential impact of water quality on the spread and control of COVID-19 in Syrian refugee camps in Lebanon. Water Int 45(5):423-429. https://doi.org/10.1080/ 02508060.2020.1780042

Kato R, Asami T, Utagawa E, Furumai H, Katayama H (2018) Pepper mild mottle virus as a process indicator at drinking water treatment plants employing coagulation-sedimentation, rapid sand filtration, 
ozonation, and biological activated carbon treatments in Japan. Water Res 132:61-70. https://doi.org/10.1016/j.watres.2017.12.068

Keulertz M, Mulligan M, Allan JA (2020) The impact of COVID-19 on water and food systems: flattening the much bigger curve ahead. Water Int 45(5):1-5. https://doi.org/10.1080/02508060.2020. 1779515

Kitajima M, Ahmed W, Bibby K, Carducci A, Gerba CP, Hamilton KA., Haramoto E, \& Rose JB (2020). SARS-CoV-2 in wastewater: state of the knowledge and research needs. In Science of the Total Environment (Vol. 739). Elsevier B.V. https://doi.org/10.1016/j. scitotenv.2020.139076

Kocamemi BA, Kurt H, Hacioglu S, Yarali C, Saatci AM, \& Pakdemirli B (2020a). First data-set on SARS-CoV-2 detection for Istanbul wastewaters in Turkey Authors Marmara University, Department of Environmental Engineering, Istanbul, Turkey Saglik Bilimleri University, Faculty of Medicine, Department of Medical Biology, Istanbul. MedRxiv, 2-11.

Kocamemi BA, Kurt ., Sait A, Sarac F, Saatci AM, \& Pakdemirli B (2020b). SARS-CoV-2 detection in Istanbul wastewater treatment plant sludges. MedRxiv, 7. https://doi.org/10.1101/2020.05.12. 20099358

Kontoangelos K, Economou M, Papageorgiou C (2020) Mental health effects of COVID-19 pandemia: a review of clinical and psychological traits. Psychiatry Investig 17(6):491-505. https://doi.org/10. 30773/pi.2020.0161

Kouhsari E, Azizian K, Sholeh M, Shayestehpour M, Hashemian M, Karamollahi S, Yaghoubi S, Sadeghiifard N (2020) Clinical, epidemiological, laboratory, and radiological characteristics of novel Coronavirus (2019-nCoV) in retrospective studies: a systemic review and meta-analysis. Indian J Med Microbiol xxxx:104-115. https://doi.org/10.1016/j.ijmmb.2020.10.004

Kumar M, Mohapatra S, Mazumder P, Singh A, Honda R, Lin C, Kumari R, Goswami R, Jha PK, Vithanage M, Kuroda K (2020) Making waves perspectives of modelling and monitoring of SARS-CoV-2 in aquatic environment for COVID-19 pandemic. Curr Pollut Rep 6 (4):468-479. https://doi.org/10.1007/s40726-020-00161-5

Kumar M, Alamin M, Kuroda K, Dhangar K, Hata A, Yamaguchi H, Honda R (2021a) Potential discharge, attenuation and exposure risk of SARS-CoV-2 in natural water bodies receiving treated wastewater. Npj Clean Water 4(1):1-11. https://doi.org/10.1038/s41545021-00098-2

Kumar M, Kuroda K, Patel AK, Patel N, Bhattacharya P, Joshi M, Joshi CG (2021b) Decay of SARS-CoV-2 RNA along the wastewater treatment outfitted with Upflow Anaerobic Sludge Blanket (UASB) system evaluated through two sample concentration techniques. Sci Total Environ 754:142329. https://doi.org/10.1016/j. scitotenv.2020.142329

Kumar M, Joshi M, Arbind Kumar Patel CGJ (2021c) Unravelling the early warning capability of wastewater surveillance for COVID-19: a temporal study on SARS-CoV-2 RNA detection and need for the escalation. Sci Total Environ 196:135907. https://doi.org/10.1016/j. envres.2021.110946

La Rosa G, Bonadonna L, Lucentini L, Kenmoe S, Suffredini E (2020a) Coronavirus in water environments: occurrence, persistence and concentration methods - A scoping review. Water Res 179: 115899. https://doi.org/10.1016/j.watres.2020.115899

La Rosa G, Iaconelli M, Mancini P, Bonanno Ferraro G, Veneri C, Bonadonna L, Lucentini L, Suffredini E (2020b) First detection of SARS-CoV-2 in untreated wastewaters in Italy. Sci Total Environ 736:139652. https://doi.org/10.1016/j.scitotenv.2020.139652

Lahrich S, Laghrib F, Farahi A, Bakasse M, Saqrane S, El Mhammedi MA (2021) Review on the contamination of wastewater by COVID19 virus: impact and treatment. Sci Total Environ 751:142325. https://doi.org/10.1016/j.scitotenv.2020.142325
Lapolla P, Lee R, \& Mingoli A (2020). Wastewater as a red flag in COVID-19 spread. In Public Health (Vol. 185, p. 26). Elsevier B. V. https://doi.org/10.1016/j.puhe.2020.05.045

Lekamwasam R, Lekamwasam S (2020) Effects of covid-19 pandemic on health and wellbeing of older people: a comprehensive review. Ann Geriatric Med Res 24(3):166-172. https://doi.org/10.4235/ agmr.20.0027

Li Q, Guan X, Wu P, Wang X, Zhou L, Tong Y, Ren R, Leung KSM, Lau EHY, Wong JY, Xing X, Xiang N, Wu Y, Li C, Chen Q, Li D, Liu T, Zhao J, Liu M et al (2020) Early transmission dynamics in Wuhan, China, of novel coronavirus-infected pneumonia. N Engl J Med 382(13):1199-1207. https://doi.org/10.1056/nejmoa2001316

Lu CW, Liu XF, Jia ZF (2020) 2019-nCoV transmission through the ocular surface must not be ignored. Lancet 395(10224):e39. https://doi.org/10.1016/S0140-6736(20)30313-5

Mahlknecht J, Padilla Reyes DA, Ramos E, Reyes LM, Álvarez MM (2021) The presence of SARS-CoV-2 RNA in different freshwater environments in urban settings determined by RT-qPCR: implications for water safety. Sci Total Environ 784:147183. https://doi.org/ 10.1016/j.scitotenv.2021.147183

Mandal P, Gupta AK, Dubey BK (2020) A review on presence, survival, disinfection/removal methods of coronavirus in wastewater and progress of wastewater-based epidemiology. J Environ Chem Eng 8(5):104317. https://doi.org/10.1016/j.jece.2020.104317

Manigandan S, Wu MT, Ponnusamy VK, Raghavendra VB, Pugazhendhi A, Brindhadevi K (2020a) A systematic review on recent trends in transmission, diagnosis, prevention and imaging features of COVID-19. Process Biochem 98(August):233-240. https://doi.org/10.1016/j.procbio.2020.08.016

Manigandan S, Wu MT, Ponnusamy VK, Raghavendra VB, Pugazhendhi A, \& Brindhadevi K (2020b). A systematic review on recent trends in transmission, diagnosis, prevention and imaging features of COVID-19. In Process Biochemistry (Vol. 98, pp. 233240). Elsevier Ltd. https://doi.org/10.1016/j.procbio.2020.08.016

Matterne U, Egger N, Tempes J, Tischer C, Lander J, Dierks ML, Bitzer EM, Apfelbacher C (2020) Health literacy in the general population in the context of epidemic or pandemic coronavirus outbreak situations: rapid scoping review. Patient Educ Couns 104(2):223-234. https://doi.org/10.1016/j.pec.2020.10.012

Medema G, Heijnen L, Elsinga G, Italiaander R, Brouwer A (2020) Presence of SARS-Coronavirus-2 RNA in sewage and correlation with reported COVID-19 prevalence in the early stage of the epidemic in the Netherlands. Environ Sci Technol Lett 7(7):511-516. https://doi.org/10.1021/acs.estlett.0c00357

Mordecai GJ, Hewson I (2020) Coronaviruses in the sea. Front Microbiol 11(July):1-6. https://doi.org/10.3389/fmicb.2020.01795

Mukherjee A, Babu SS, Ghosh S (2020) Thinking about water and air to attain sustainable development goals during times of COVID-19 pandemic. J Earth Syst Sci 129(1). https://doi.org/10.1007/s12040020-01475-0

Naddeo V, Liu H (2020) Editorial perspectives: 2019 novel coronavirus (SARS-CoV-2): what is its fate in urban water cycle and how can the water research community respond? Environ Sci: Water Research and Technology 6(5):1213-1216. https://doi.org/10.1039/ d0ew $90015 j$

Naser N, Masic I, Zildzic M (2020) Public health aspects of COVID19 infection with focus on cardiovascular diseases. Mater Socio Med 32(1):71. https://doi.org/10.5455/msm.2020.32.71-76

Neal MJ (2020) COVID-19 and water resources management: reframing our priorities as a water sector. Water Int 45(5):435-440. https://doi. org/10.1080/02508060.2020.1773648

Nemudryi A, Nemudraia A, Wiegand T, Surya K, Buyukyoruk M, Vanderwood KK, Wilkinson R, \& Wiedenheft B (2020). Temporal detection and phylogenetic assessment of SARS-CoV-2 in municipal wastewater. In medRxiv. medRxiv. https://doi.org/10. $1101 / 2020.04 .15 .20066746$ 
Noorimotlagh Z, Jaafarzadeh N, Martínez SS, Mirzaee SA (2021) A systematic review of possible airborne transmission of the COVID-19 virus (SARS-CoV-2) in the indoor air environment. Environ Res 193(December 2020):110612. https://doi.org/10. 1016/j.envres.2020.110612

O'Brien E, Xagoraraki I (2019) A water-focused one-health approach for early detection and prevention of viral outbreaks. One Health 7 (November 2018):100094. https://doi.org/10.1016/j.onehlt.2019. 100094

Pandey D, Verma S, Verma P, Mahanty B, Dutta K, Daverey A, \& Arunachalam K (2021). SARS-CoV-2 in wastewater: challenges for developing countries. In International Journal of Hygiene and Environmental Health (Vol. 231). https://doi.org/10.1016/j.ijheh. 2020.113634

Parthasarathy P, Vivekanandan S (2021) An extensive study on the COVID-19 pandemic, an emerging global crisis: risks, transmission, impacts and mitigation. J Infect Public Health 14(2):249-259. https://doi.org/10.1016/j.jiph.2020.12.020

Peccia J, Zulli A, Brackney DE, Grubaugh ND, Kaplan EH, CasanovasMassana A, Ko AI, Malik AA, Wang D, Wang M, Warren JL, Weinberger DM, Omer SB (2020) SARS-CoV-2 RNA concentrations in primary municipal sewage sludge as a leading indicator of COVID-19 outbreak dynamics. MedRxiv 1:203. https://doi.org/10. 1101/2020.05.19.20105999

Platto S, Zhou J, Wang Y, Wang H, Carafoli E (2020) Biodiversity loss and COVID-19 pandemic: the role of bats in the origin and the spreading of the disease. Biochem Biophys Res Commun. https:// doi.org/10.1016/j.bbrc.2020.10.028

Poch M, Garrido-Baserba M, Corominas L, Perelló-Moragues A, Monclús H, Cermerón-Romero M, Melitas N, Jiang SC, Rosso D (2020) When the fourth water and digital revolution encountered COVID-19. Sci Total Environ 744:140980. https://doi.org/10. 1016/j.scitotenv.2020.140980

Polo D, Quintela-Baluja M, Corbishley A, Jones DL, Singer AC, Graham DW, Romalde JL (2020) Making waves: wastewater-based epidemiology for COVID-19 - approaches and challenges for surveillance and prediction. Water Res 186:116404. https://doi.org/10. 1016/j.watres.2020.116404

Purnama SG, \& Susanna D (2020). Hygiene and sanitation challenge for covid-19 prevention in Indonesia. Kesmas, 15(2). https://doi.org/10. 21109/KESMAS.V15I2.3932

Quinete N, Hauser-Davis RA (2021) Drinking water pollutants may affect the immune system: concerns regarding COVID-19 health effects. Environ Sci Pollut Res 28(1):1235-1246. https://doi.org/10. 1007/s11356-020-11487-4

Randazzo W, Truchado P, Cuevas-Ferrando E, Simón P, Allende A, \& Sánchez G (2020). SARS-CoV-2 RNA titers in wastewater anticipated COVID-19 occurrence in a low prevalence area. In medRxiv. medRxiv. https://doi.org/10.1101/2020.04.22.20075200

Ranscombe P (2020) Rural areas at risk during COVID-19 pandemic. Lancet Infect Dis 20(5):545. https://doi.org/10.1016/S1473-3099 (20)30301-7

Rashed MN, Hussein AAM, Ismail AMI, Galal I (2020) Impact of COVID 19 Pandemic on the World Environment. Aswan Univ J Environ Stud 1(1):3-12. https://doi.org/10.21608/aujes.2020. 124527

Rimoldi SG, Stefani F, Gigantiello A, Polesello S, Comandatore F, Mileto D, Maresca M, Longobardi C, Mancon A, Romeri F, Pagani C, Cappelli F, Roscioli C, Moja L, Gismondo MR, Salerno F (2020) Presence and infectivity of SARS-CoV-2 virus in wastewaters and rivers. Sci Total Environ 744:140911. https://doi.org/10. 1016/j.scitotenv.2020.140911

Rodríguez RA, Pepper IL, Gerba CP (2009) Application of PCR-based methods to assess the infectivity of enteric viruses in environmental samples. Appl Environ Microbiol 75(2):297-307. https://doi.org/10. 1128/AEM.01150-08
Rothan HA, Byrareddy SN (2020) The epidemiology and pathogenesis of coronavirus disease (COVID-19) outbreak. J Autoimmun 109 (February):102433. https://doi.org/10.1016/j.jaut.2020.102433

Rume T, Islam SMDU (2020) Environmental effects of COVID-19 pandemic and potential strategies of sustainability. Heliyon 6(9): e04965. https://doi.org/10.1016/j.heliyon.2020.e04965

Rupani PF, Nilashi M, Abumalloh RA, Asadi S, Samad S, Wang S (2020) Coronavirus pandemic (COVID-19) and its natural environmental impacts. Int J Environ Sci Technol 17(11):4655-4666. https://doi.org/10.1007/s13762-020-02910-x

Salvador D, Neto C, Benoliel MJ, \& Filomena Caeiro M (2020). Assessment of the presence of hepatitis $\mathrm{E}$ virus in surface water and drinking water in Portugal. Microorganisms, 8(5). https://doi. org/10.3390/microorganisms 8050761

Scagnolari C, Bitossi C, Viscido A, Frasca F, Oliveto G, Scordio M, Petrarca L, Mancino E, Nenna R, Riva E, De Vito C, Midulla F, Antonelli G, Pierangeli A (2021) ACE2 expression is related to the interferon response in airway epithelial cells but is that functional for SARS-CoV-2 entry? Cytokine 140(December 2020):155430. https://doi.org/10.1016/j.cyto.2021.155430

Sepúlveda-Loyola W, Rodríguez-Sánchez I, Pérez-Rodríguez P, Ganz F, Torralba R, Oliveira DV, Rodríguez-Mañas L (2020) Impact of social isolation due to COVID-19 on health in older people: mental and physical effects and recommendations. J Nutr Health Aging 24: 938-947. https://doi.org/10.1007/s12603-020-1469-2

Shang Y, Tao Y, Dong J, He F, Tu J (2021) Deposition features of inhaled viral droplets may lead to rapid secondary transmission of COVID19. J Aerosol Sci 154(November 2020):105745. https://doi.org/10. 1016/j.jaerosci.2021.105745

Sharifi A, Khavarian-Garmsir AR (2020) The COVID-19 pandemic: impacts on cities and major lessons for urban planning, design, and management. Sci Total Environ 749:1-3. https://doi.org/10.1016/j. scitotenv.2020.142391

Sherchan SP, Shahin S, Ward LM, Tandukar S, Aw TG, Schmitz B, Ahmed W, Kitajima M (2020) First detection of SARS-CoV-2 RNA in wastewater in North America: a study in Louisiana, USA. Sci Total Environ 743:140621. https://doi.org/10.1016/j.scitotenv. 2020.140621

Shereen MA, Khan S, Kazmi A, Bashir N, Siddique R (2020) COVID-19 infection: origin, transmission, and characteristics of human coronaviruses. J Adv Res 24:91-98. https://doi.org/10.1016/j.jare. 2020.03.005

Shirato K, Nao N, Katano H, Takayama I, Saito S, Kato F, Katoh H, Sakata M, Nakatsu Y, Mori Y, Kageyama T, Matsuyama S, Takeda M (2020) Development of genetic diagnostic methods for detection for novel coronavirus 2019(nCoV-2019) in Japan. Jpn J Infect Dis 73(4):304-307. https://doi.org/10.7883/yoken.JJID.2020.061

Shutler JD, Zaraska K, Holding T, Machnik M, Uppuluri K, Ashton IGC, Migda $€, \&$ Dahiya RS (2021). Rapid assessment of SARS-CoV - 2 transmission risk for fecally contaminated river water. https://doi. org/10.1021/acsestwater.0c00246

Sinclair TR, Robles D, Raza B, van den Hengel S, Rutjes SA, de Roda Husman AM, de Grooth J, de Vos WM, Roesink HDW (2018) Virus reduction through microfiltration membranes modified with a cationic polymer for drinking water applications. Colloids Surf A Physicochem Eng Asp 551:33-41. https://doi.org/10.1016/j. colsurfa.2018.04.056

Sivakumar B (2020) COVID-19 and water. Stoch Env Res Risk A 6:10 13. https://doi.org/10.1007/s00477-020-01837-6

Spearing LA, Thelemaque N, Kaminsky JA, Katz LE, Kinney KA, Kirisits MJ, Sela L, Faust KM (2020) Implications of Social distancing policies on drinking water infrastructure: an overview of the challenges to and responses of U.S. Utilities during the COVID-19 Pandemic. ACS ES\&T Water. https://doi.org/10.1021/acsestwater. 0c00229 
States S (2020) Epidemic/pandemic emergency planning for water utilities. J Am Water Works Assoc 112(12):26-33. https://doi.org/10. 1002/awwa.1631

Stookey JD, Allu PKR, Chabas D, Pearce D, Lang F (2020) Hypotheses about sub-optimal hydration in the weeks before coronavirus disease (COVID-19) as a risk factor for dying from COVID-19. Med Hypotheses 144:110237. https://doi.org/10.1016/j.mehy.2020. 110237

Street R, Malema S, Mahlangeni N, Mathee A (2020) Wastewater surveillance for Covid-19: an African perspective. Sci Total Environ 743:140719. https://doi.org/10.1016/j.scitotenv.2020.140719

Tarighi P, Eftekhari S, Chizari M, Sabernavaei M, Jafari D, Mirzabeigi P (2021) A review of potential suggested drugs for coronavirus disease (COVID-19) treatment. Eur J Pharmacol 895(December 2020): 173890. https://doi.org/10.1016/j.ejphar.2021.173890

Tran HN, Le GT, Nguyen DT, Juang RS, Rinklebe J, Bhatnagar A, Lima EC, Iqbal HMN, Sarmah AK, Chao HP (2021) SARS-CoV-2 coronavirus in water and wastewater: a critical review about presence and concern. Environ Res 193:110265. https://doi.org/10.1016/j. envres.2020.110265

Trang NV, Choisy M, Nakagomi T, Chinh NTM, Doan YH, Yamashiro T, Bryant JE, Nakagomi O, Anh DD (2015) Determination of cutoff cycle threshold values in routine RT-PCR assays to assist differential diagnosis of norovirus in children hospitalized for acute gastroenteritis. Epidemiol Infect 143(15):3292-3299. https://doi.org/ $10.1017 / \mathrm{S} 095026881500059 \mathrm{X}$

Tu YP, O'Leary TJ (2020) Testing for severe acute respiratory syndromecoronavirus 2: Challenges in getting good specimens, choosing the right test, and interpreting the results. Crit Care Med 48:1680-1689. https://doi.org/10.1097/CCM.0000000000004594

Ullah H, Ullah A, Gul A, Mousavi T, Khan MW (2020) Novel coronavirus 2019 (COVID-19) pandemic outbreak: a comprehensive review of the current literature. Vacunas 2019(x x):106-113. https:// doi.org/10.1016/j.vacun.2020.09.009

Vogels CBF, Brito AF, Wyllie AL, Fauver JR, Ott IM, Kalinich CC, Petrone ME, Casanovas-Massana A, Catherine Muenker M, Moore AJ, Klein J, Lu P, Lu-Culligan A, Jiang X, Kim DJ, Kudo E, Mao T, Moriyama M, Oh JE et al (2020) Analytical sensitivity and efficiency comparisons of SARS-CoV-2 RT-qPCR primerprobe sets. Nat Microbiol 5(10):1299-1305. https://doi.org/10. 1038/s41564-020-0761-6

Wan Y, Shang J, Graham R, Baric RS, Li F (2020) Receptor recognition by the novel coronavirus from Wuhan: an analysis based on decadelong structural studies of SARS coronavirus. J Virol 94(7): e0012720. https://doi.org/10.1128/jvi.00127-20

Wang J, Shen J, Ye D, Yan X, Zhang Y, Yang W, Li X, Wang J, Zhang L, Pan L (2020a) Disinfection technology of hospital wastes and wastewater: suggestions for disinfection strategy during coronavirus Disease 2019 (COVID-19) pandemic in China. Environ Pollut 262: 114665. https://doi.org/10.1016/j.envpol.2020.114665

Wang J, Feng H, Zhang S, Ni Z, Ni L, Chen Y, Zhuo L, Zhong Z, Qu T (2020b) SARS-CoV-2 RNA detection of hospital isolation wards hygiene monitoring during the Coronavirus Disease 2019 outbreak in a Chinese hospital. Int J Infect Dis 94(January 2019):103-106. https://doi.org/10.1016/j.ijid.2020.04.024
Weidhaas J, Aanderud ZT, Roper DK, VanDerslice J, Gaddis EB, Ostermiller J, Hoffman K, Jamal R, Heck P, Zhang Y, Torgersen $\mathrm{K}$, Laan JV, LaCross N (2021) Correlation of SARS-CoV-2 RNA in wastewater with COVID-19 disease burden in sewersheds. Sci Total Environ 775:145790. https://doi.org/10.1016/j.scitotenv.2021. 145790

WHO. (2020). Laboratory biosafety guidance related to the novel coronavirus ( 2019-nCoV ). Who, February, 1-12. https://www.who.int/ docs/default-source/coronaviruse/laboratory-biosafety-novelcoronavirus-version-1-1.pdf?sfvrsn=912a9847 2

WHO. (2021). Coronavirus disease 2021 (COVID-19). Situation report. https://iris.paho.org/handle/10665.2/53237

Wu FQ, Xiao A, Zhang JB, Gu XQ, Lee WL, Kauffman K, Hanage WP, Matus M, Ghaeli N, Endo N, Duvallet C, Moniz K, Erickson TB, Chai PR, Thompson J, \& Alm EJ (2020). SARS-CoV-2 titers in wastewater are higher than expected from clinically confirmed cases. In medRxiv. medRxiv. https://doi.org/10.1101/2020.04.05. 20051540

Wurtzer S, Marechal V, Mouchel JM, Maday Y, Teyssou R, Richard E, Almayrac JL, Moulin L (2020a) Evaluation of lockdown effect on SARS-CoV-2 dynamics through viral genome quantification in waste water, Greater Paris, France, 5 March to 23 April 2020. Eurosurveillance 25(50):2000776. https://doi.org/10.2807/15607917.ES.2020.25.50.2000776

Wurtzer S, Marechal V, Mouchel JM, Maday Y, Teyssou R, Richard E, Almayrac JL, \& Moulin L (2020b). Evaluation of lockdown impact on SARS-CoV-2 dynamics through viral genome quantification in Paris wastewaters. In medRxiv. medRxiv. https://doi.org/10.1101/ 2020.04.12.20062679

Zaneti RN, Girardi V, Spilki FR, Mena K, Westphalen APC, da Costa Colares ER, Pozzebon AG, Etchepare RG (2021) Quantitative microbial risk assessment of SARS-CoV-2 for workers in wastewater treatment plants. Sci Total Environ 754:142163. https://doi.org/10. 1016/j.scitotenv.2020.142163

Zhang D, Ling H, Huang X, Li J, Li W, Yi C, Zhang T, Jiang Y, He Y, Deng S, Zhang X, Wang X, Liu Y, Li G, Qu J (2020) Potential spreading risks and disinfection challenges of medical wastewater by the presence of severe acute respiratory syndrome coronavirus 2 (SARS-CoV-2) viral RNA in septic tanks of Fangcang Hospital. Sci Total Environ 741:140445. https://doi.org/10.1016/j.scitotenv.2020. 140445

Zhou Z, Yang Z, Ou J, Zhang H, Zhang Q, Dong M, Zhang G (2021) Temperature dependence of the SARS-CoV-2 affinity to human ACE2 determines COVID-19 progression and clinical outcome. Comp Struct Biotechnol J 19:161-167. https://doi.org/10.1016/j. csbj.2020.12.005

Zvobgo L, Do P (2020) COVID-19 and the call for 'Safe Hands': Challenges facing the under-resourced municipalities that lack potable water access - a case study of Chitungwiza municipality, Zimbabwe. Water Res X 9:100074. https://doi.org/10.1016/j.wroa. 2020.100074

Publisher's note Springer Nature remains neutral with regard to jurisdictional claims in published maps and institutional affiliations. 